\title{
المنهج المعرفي التوحيدي عند عبد الوهاب المسيري: مدخل إلى الإبستمولوجيا التوحيدية
}

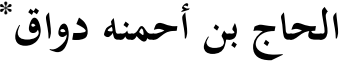

$$
\begin{aligned}
& \text { الملنحص } \\
& \text { سعى البحث إلى تحليل جهود عبد الوهاب المسيري في ملاحظة فشل المناهج المادية التي تبناها الغرب في صياغة } \\
& \text { المعرفة ونقدها، وتوظيفها في صياغة الواقع الإنساني. وقد تبين للمسيري أن سبب هذا الفشل هو بُعد المناهج المادية }
\end{aligned}
$$

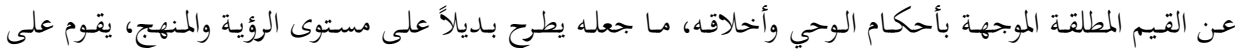

$$
\begin{aligned}
& \text { النموذج المعري التوحيدي، الذي يبحث في أصول الظواهر ومآلاتما، ويقرأ فيها الإلهي المتجاوز. } \\
& \text { الكلمـات المفتاحيـة: عبد الوهـاب المسيري، الرؤية التوحيدية، المنهج التوحيدي، العلمانية، النموذج المعريف، } \\
& \text { النموذج التحليلي البسيط، النموذج التحليلي المركب. }
\end{aligned}
$$

\section{An Introduction to Abdelwahab El Messiri's Tawhidi Epistemology}

\section{Abstract}

This study has analyzed efforts of Abdelwahab El-Messiri in his observation of the failure of Western materialism in formulating and testing knowledge, and the shaping of human life. El-messiri has found that this failure is due to material approach which is devoid of values guided by revelation and its ethics. El-Messiri has suggested the Tawhidi epistemology as an alternative. This alternative epistemology would study the origins of the phenomena under study, and its ends, and conclude with presence of the divine.

Keywords: Abdelwahab El-Messiri, tawhidi worldview, tawhidi paradigm, secularism, paradigm, simple analytical paradigm, and composite analytical paradigm.

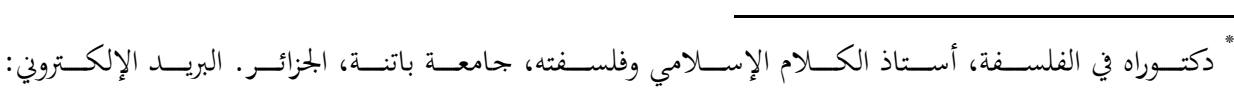

$$
\begin{aligned}
& \text { elhadj_1971@yahoo.fr }
\end{aligned}
$$

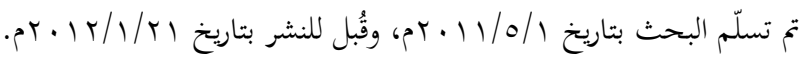




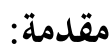

لم تعد الممارسة المعرفية في نطاق الفكر الإسلامي المعاصر مقتصرة على ردات الفعل

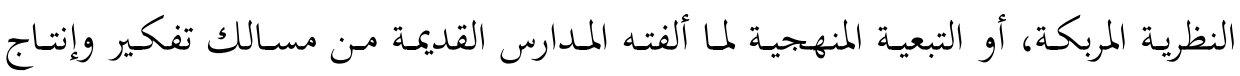

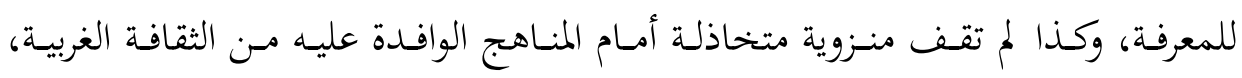

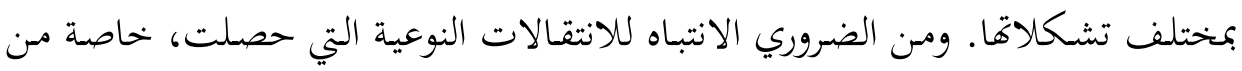

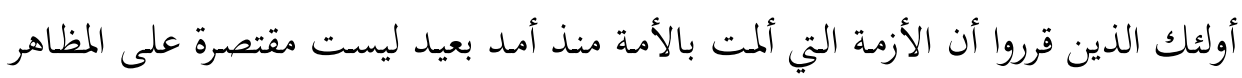

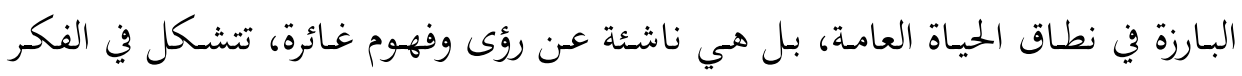

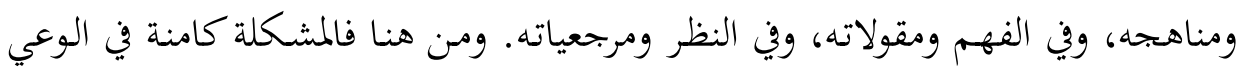

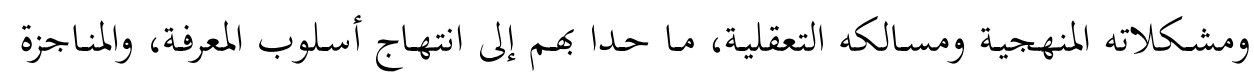

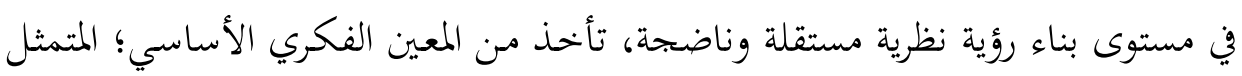

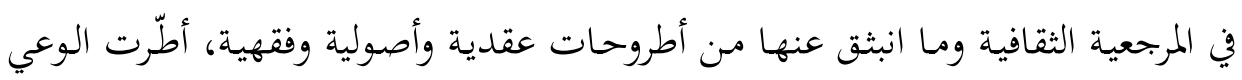
العام والممارسة التابعة له.

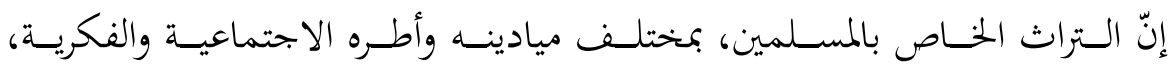

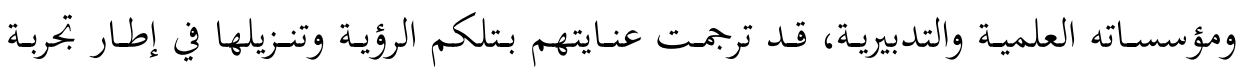

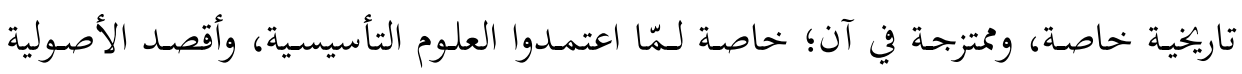

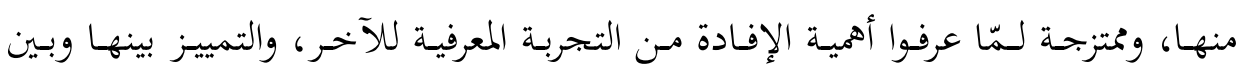

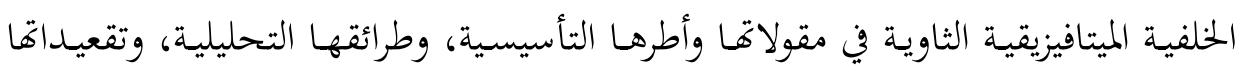

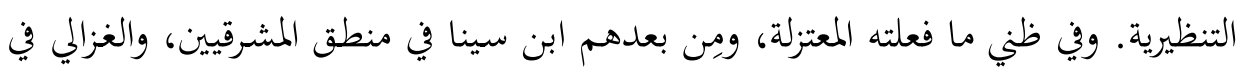

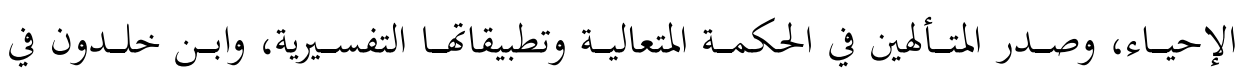

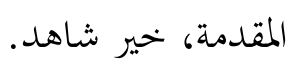

يضاف إلى ذلك أن المسلمين قد استعانوا بصورة ذكية ومميزة بمناهج المعرفة المعاصرة،

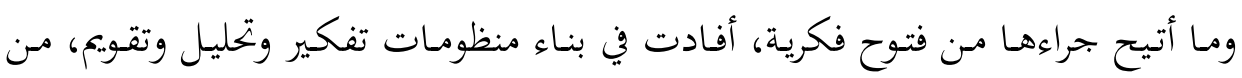

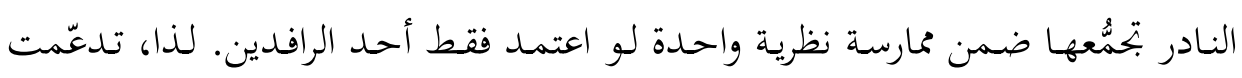


VY المنهج المعري التوحيدي عند عبد الوهاب المسيري: مدخل إلى الإبستمولوجيا التوحيدية الحاج بن أحمنة دواق

المدرسة التوحيدية بمشاريع فكرية مركبة ومتوزعة العناية والاهتمام، استطاعت أن تنظر إلى المشكلات التي ألمّت بوعي الإنسان المعاصر، بنوع من الكفاءة المستصحبة لثراء المصادر

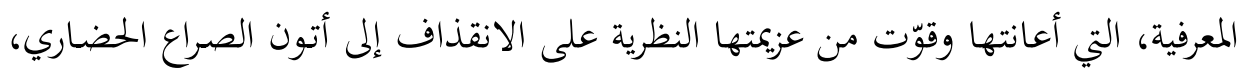
من صوره البسيطة، إلى أفقه التاريخي والحضاري العام.

وفي حسدود مـا قرأت في فكرنـا العربي والإسـلامي المعاصـر، قلائسل هـم الـذين كتبـوا بالسمات التي أوردها قبالاً ومـن أهم أولئك المفكر عبد الوهـاب المسيري، في مشروعه

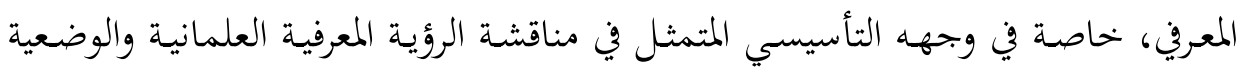
الإمبرياليـة، ثم في طرحسه البـديل النظـــي والمنهجهـي في آن؛ وأعسني بـهـ الرؤيسة المعرفيـة الإسلامية، أو ما يفضل هو تسميتها بالرؤية المعرفية التوحيدية.

ويمكننا استجماع شتات المنهج والرؤية والمذهب من بحموع مؤلفاته، خاصة المعرفية منهـا؛ وأقصـد بهـا: اللغـة والبحـاز، والفلسفة الماديـة وتفكيـك الإنسـان، والعلمانيـة الجزئيـة والشـاملة، وموسوعة اليهود واليهوديـة، خاصـة القسم النظري منهـا، والنازيـة والصهيونية

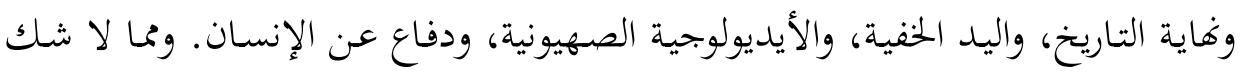

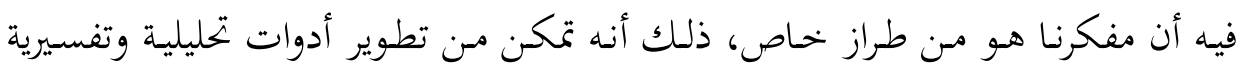

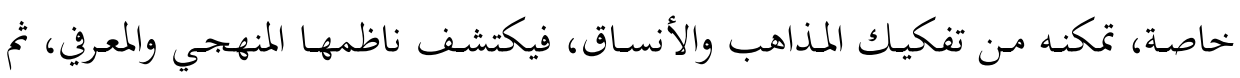
يعيد تركيبها والتأليف بين عناصرها في إطار رؤية وجودية توحيدية إنسانية تنظر إلى كرامة

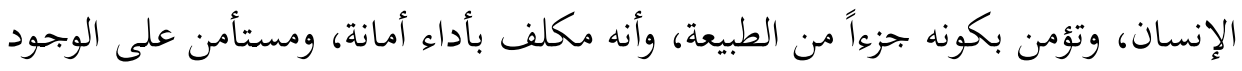

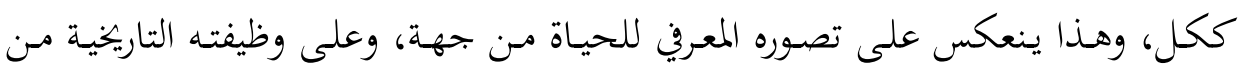
ناحية أخرى.

والتوحيد ليس تسليماً عقديّاً فحسب، وإنما هو امتداد معريف يتحدث عن المعرفة في

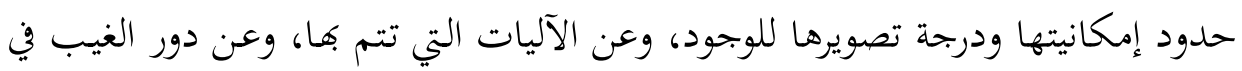

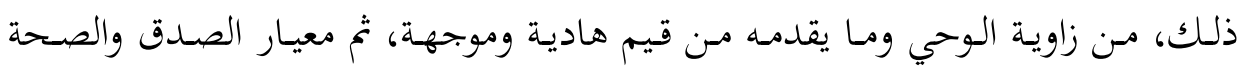

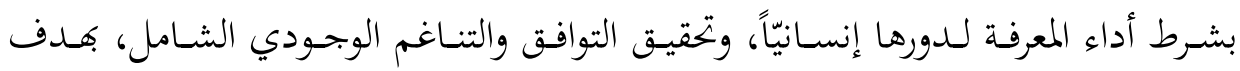

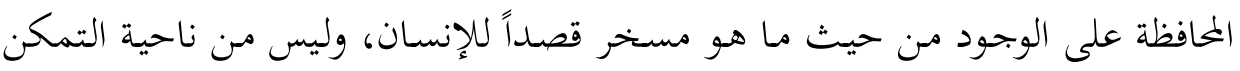


الإمبريالي منه، بهدر إمكاناته واستغلالما بـلا توازن، فينعكس ذلك على تصورنا لتطور

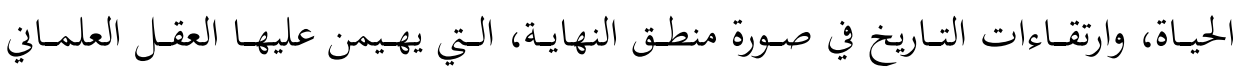
الليبرالي المادي الإمبريالي.

وبمـا أن المنهجج مفـردة معطاة ضـمن سياق، ولا يمكن التعـاطي معـه على أنه كيـان منبت، فمن الضروري وضع السياق النظري الذي يجد فيه المنهج الشبكة التصورية التي

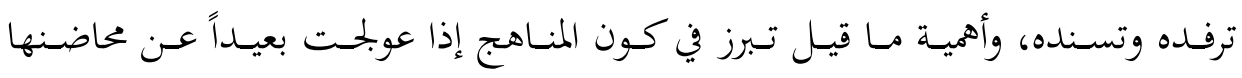

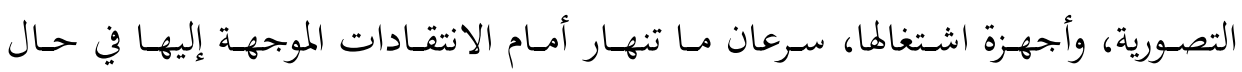
التقويم، أو فشلها في حال التطبيق. من هنا أفضي إلى المنهج المعرين التوحيدي في إطار بحاله المعريف، الذي فيه يتحرك،

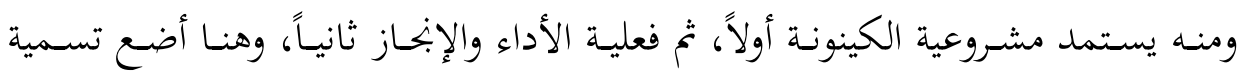
خاصـة لهـذا السـياق، فتكـون الرؤيـة الوجوديـة التوحيديـة، بوصفهـا إطـاراً وناظمـاً معرفيّاً شاملاً، أعالج فيه المنهج كصيغة إجرائية، مع تطبيقاته المختلفة.

\section{أولاً: الإطار النظري المؤسس للمنهج المعرفي التوحيدي}

أول مـا يتبـادر إلى الذهن قبـل الإفضـاء إلى التحليـل، هـو: مـا الممهـدات النظريـة،

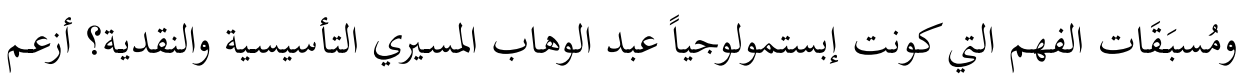

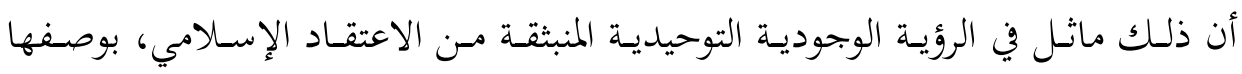
خلاصة للوعي الديني الإنساني عموماً والتوحيدي منه على سبيل التدقيق. فكما ألمح الرجل في سيرته إلى أنه انتقل من مرحلة الإنكار التام لدور العقائد في تشكيل النظريات

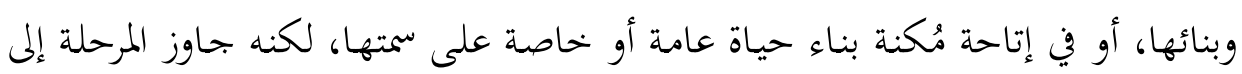

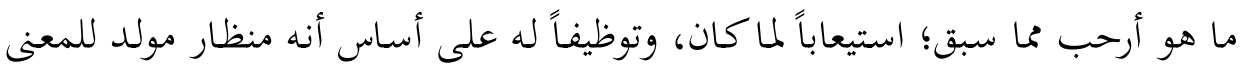
الجديد، ومؤسس للإدراك المختلف. وفي ذلك يقول: "لعل التجربة الوجودية والفكرية في حياتي هي هيمنة النموذج المادي الفلسفي عليَّ بعض الوقت (بعد أن اجتاحني الشك في دمنهور)، ثم إدراكي التدريجي بعدم جدوى النماذج التحليلية المادية في الإحاطة بالظاهرة 
Vه المنهج المعرفي التوحيدي عند عبد الوهاب المسيري: مدخل إلى الإبستمولوجيا التوحيدية الحاج بن أحمنة دواق الإنسانية المركبة (نظراً لبساطة هـذه النماذج وسذاجتها واختزاليتها، وإحساسي المتزايـد

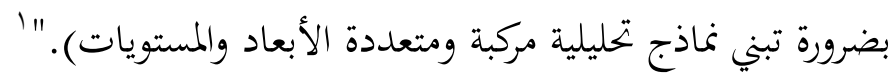

ا ـ المسيري بين الانتقال المركب، والاختيـار الواعي، أو نشوء الموقف من

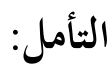

نلمح أن الانتقـال الحاصل ليس تأنيـب ضـمير، أو وخـزاً أخلاقيـاً شعر بـه، باعتبـار

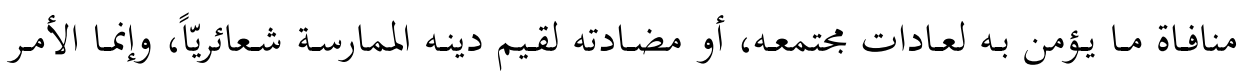

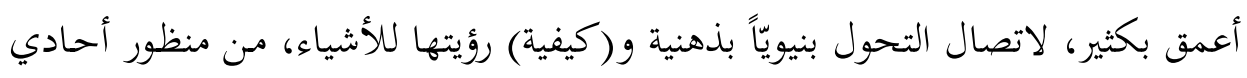

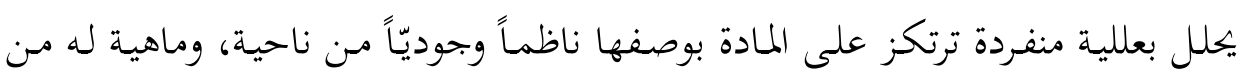
ناحية أخرى، وهو تصور يولد من الناحية الفلسفية موقفاً لا تسامح فيه مع المفارقات أو الماورائيات، وهنا انتبه المسيري للفراغ الناشئ من نمط الفهم الأحادي؛ الناتج من عجزه عن ملى النفس بطمأنينة اليقين، وإشباع الضمير بامتلاءات قيمية تفضي إلى فهم معنى الإنسانية في الحياة بمختلف امتداداها.

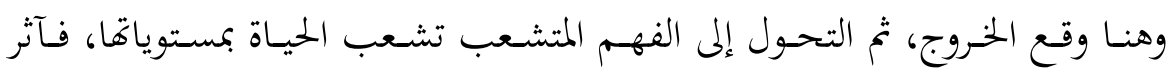

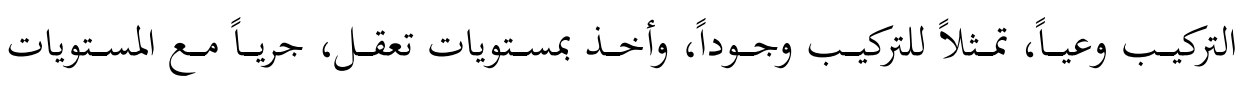
الوجوديـة الهائلـة، المتراوحهـة بـين الكائنـات الجامــدة إلى الحيـة، بلوغـاً إلى أسماهـا وأكثرهـا

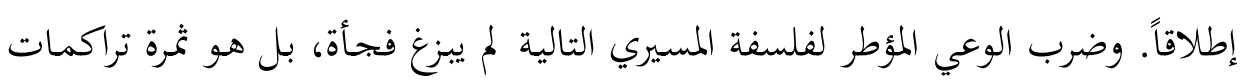

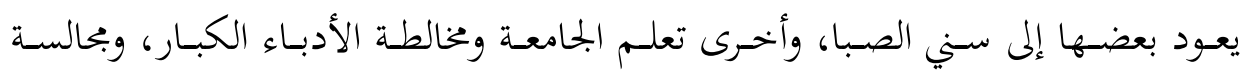
المفكرين على تنوع متناولاهم. يقول المسيري: "لم يكن هذا النموذج الإنساني غير المادي

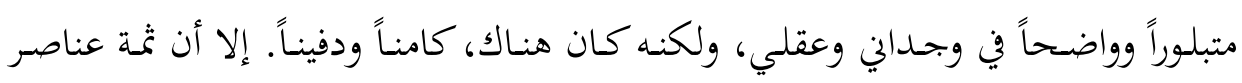

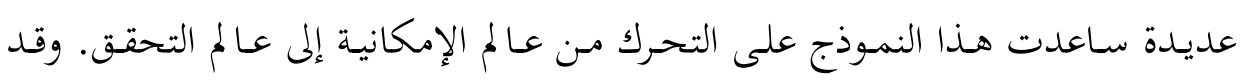
تناولت نشأتي في دمنهور والمجتمع التقليدي الذي عرفته عن قرب، بكل حسناته وسيئاته،

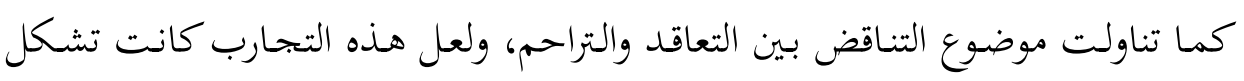


الإطسار الكلمي أو التربـة الخصبة التي صـبت فيها التجـارب الأخرى التي هـزت النمـاذج

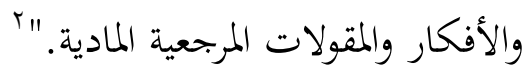

وأجلـب النظر إلى مسـمى التجربـة وأثرهـا في الوجـدان؛ فليس مـن قبيـل التعجـل أن

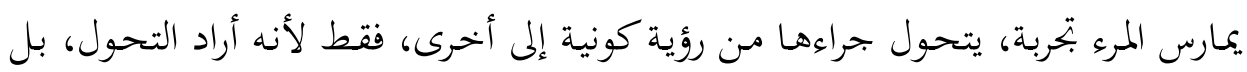

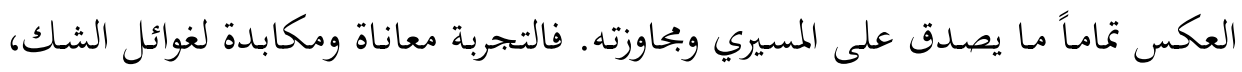

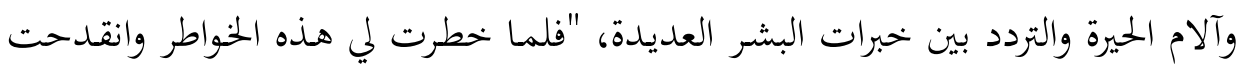

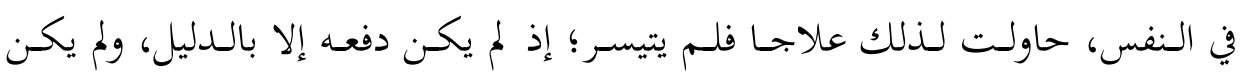

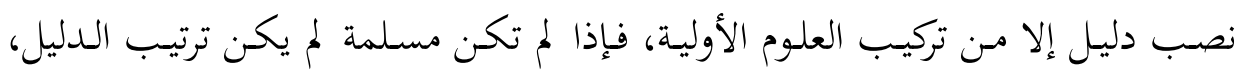

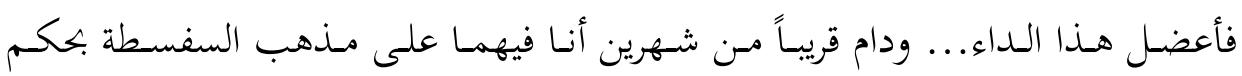

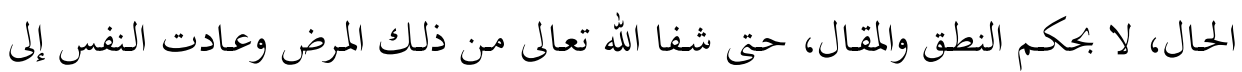

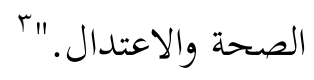

والملاحظ أن المسيري لم يبعد عن بتحبة الحضارة الإسلامية في التعاطي مع أساليب الفهم المادي للعالم وتقويمه للأشياء، وإن لم يسمّ ذلك أو يعلنه، فرفض الغرية الغيبية مقياساً في إنتاج المعرفة والحكىم على بتحارب الآخرين ونظمهم للحياة، كأثر للدراسة المعلمنة مؤقتاً.

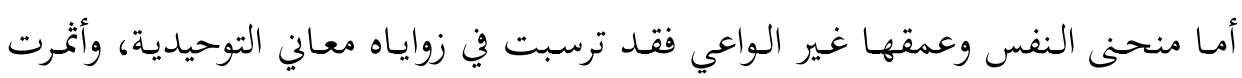

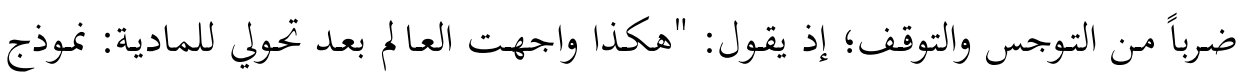
ظاهر مادي، ونموذج كامن يصل إلى الجوهر الإنساني المفارق لصيرورة المادة.... ويبدو أن

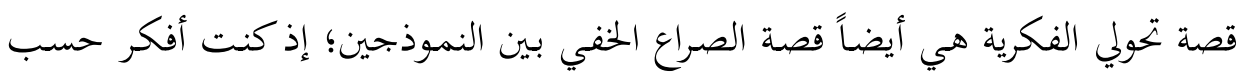

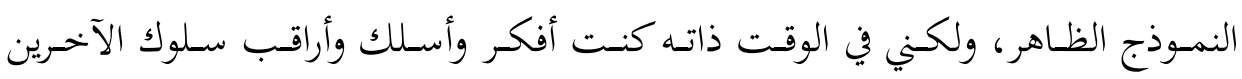

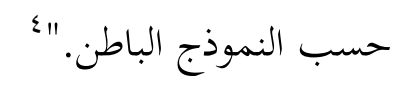

وجـدير بنـا أن نعلن العجز التكـويني في النموذج المـادي عامـة، لقعوده عـن تمكين الفيلسوف من الحكم والتقويم لأساليب الآخرين في الحياة، فيندفع بسلاسة إلى الكوامن

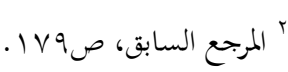

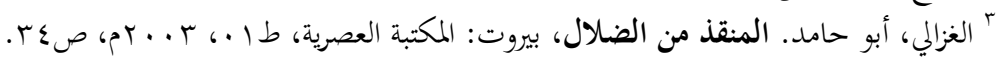

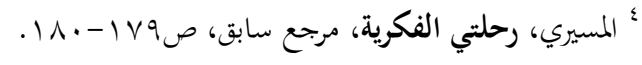


VV المنهج المعري التوحيدي عند عبد الوهاب المسيري: مدخل إلى الإبستمولوجيا التوحيدية الحاج بن أحمنة دواق

وترسباقا للسـلوك والتفكير وفقها، لتحقيـق الاستيعاب التفسيري مـن جهـة، ولانبثـاق

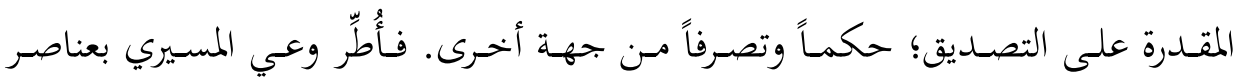

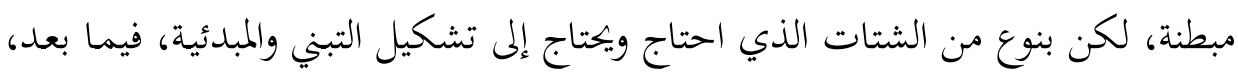
خاصة إذا أخذنا همَّ المشروع وأفقه النقدي في الحسبان.

\section{Y . مركزية الدين، ومحورية التجربة المعنوية، وإسهامهما في تأطير النموذج:}

إن إطار النظر الباعث على فهم المسيري والملح عليه باستمرار، هو الدين، كمقولة

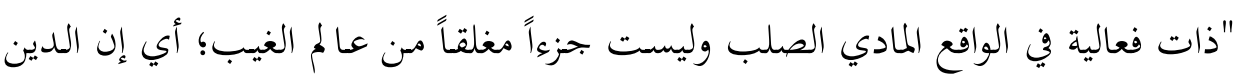

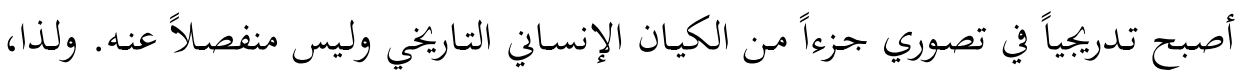

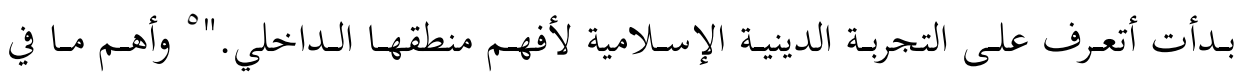

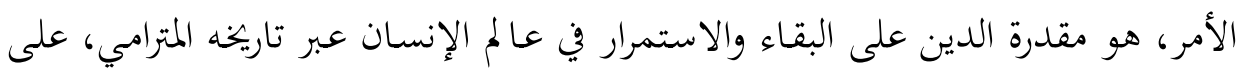

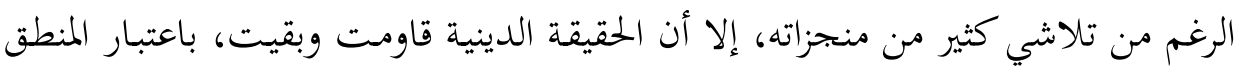

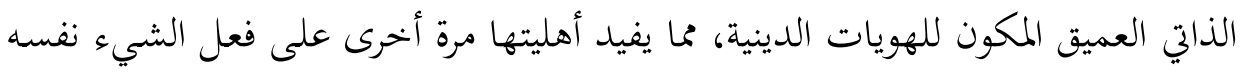
في التاريخ؛ أي الإبحاز، فتسقط مقولة غيبية الدين ومفارقته الشرط التـاريخي في التأثير؛ وأعني المحايثة والملامسة لواقع الناس الماديادي.

فأصبح الإسـام التوحيدي مرجعية المسيري واختيـاره النظري، بوصفه الأكفأ على

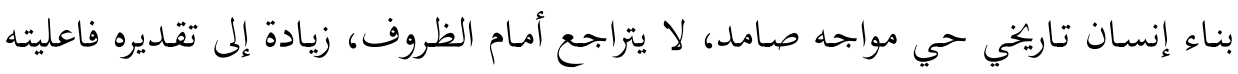

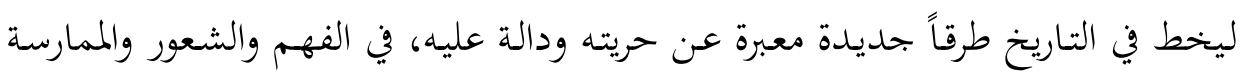
والعلاقات. وفي ذلك يقول: "ولعل العنصر الحاسم في انتقالي من عالم المادية الضيق إلى عالم أكثر رحابة، هو تبلور النموذج الكامن [سنجليه في بقية التحليل] في وجداني وتحوله

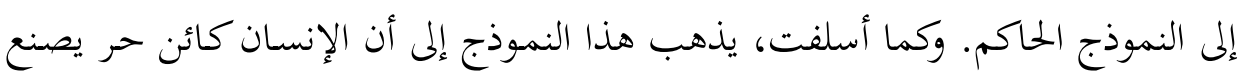

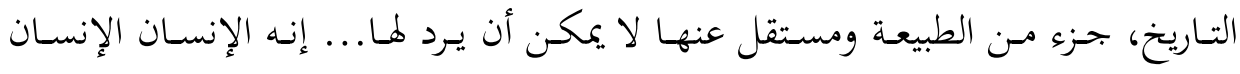

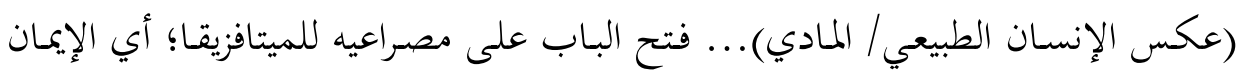

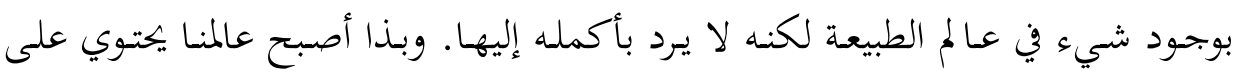




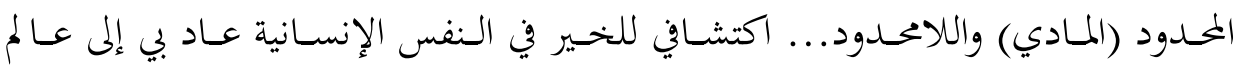

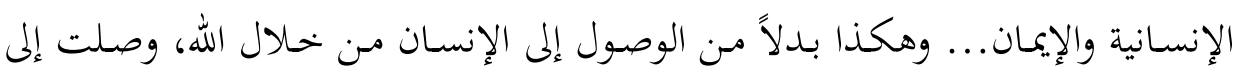
الله من خلال الإنسان. "الإنسان

فالتوحيديـة، حسـب مـا تواردت إلى فيلسـوفنا، تولدت مـن إنعـام النظر في أشكال

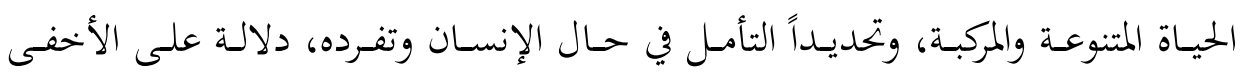
والأركز في جوهر الوجود ككل، من كينونة طبيعية ظاهرة تماثل الموجودات جميعاً، وطبيعة أخرى غير متحققة في أي منها؛ وأعني القدرة على المفاضلة بين الأشياء والتوقف إزاءها،

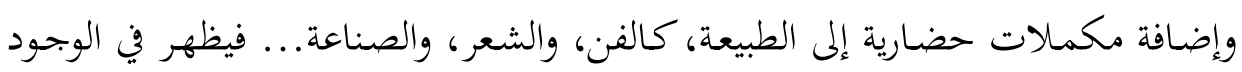

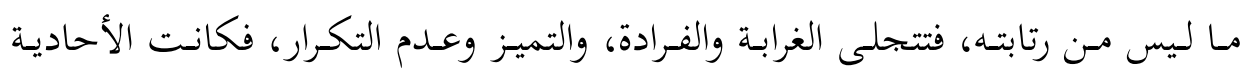

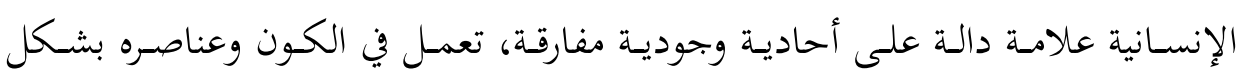
عجيب، مؤكدة تعاليها وحضورها في الآن نفسه.

\section{ثانياً: التوحيدية: نموذج معرفي بديل}

برز لنـا في تناول الإطار، مبلغ التأمـل والمعاناة اللذين مارسهما المسيري إزاء الحياة

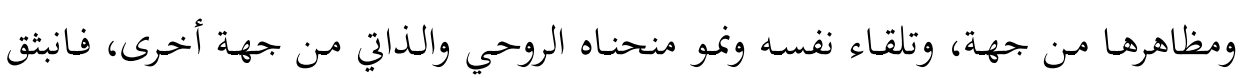
لذاك وعي نماذجي متأسس على نوع من التراتبية المشدودة إلى ناظم منهجي صارم، سماه ونهاه

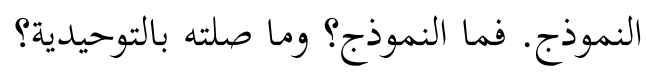

\section{1 ـ التوحيد ووصفه بنيةً جامعة لمقولات النسق:}

مـن المقـولات المركزيـة في فلسفة المسـيري فكـرة النمـوذج، الـذي يصفه بأنـه: "بنيـة

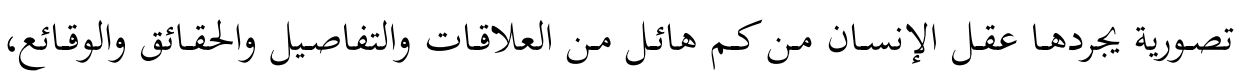
فهو يستبعد بعضها بوصفها غير دالة (من وجهة نظره) ويستبقي بعضها، ثم يربط بينها

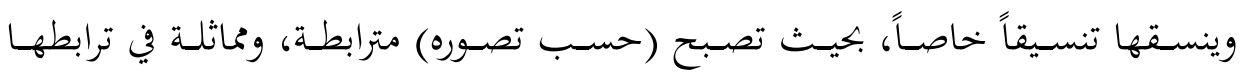




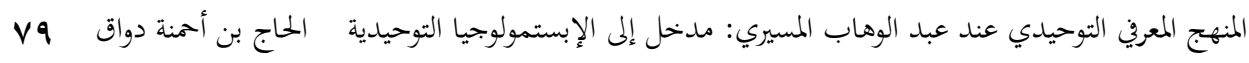

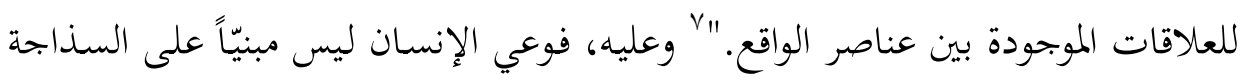

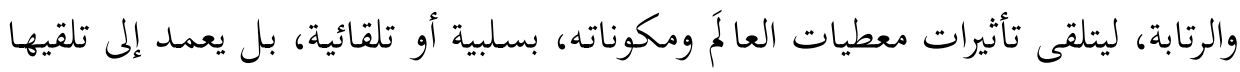

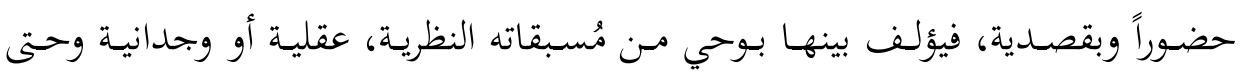

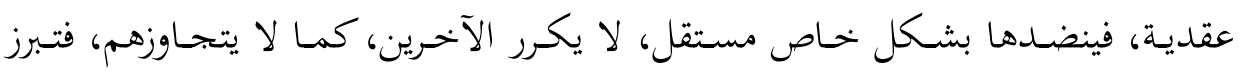

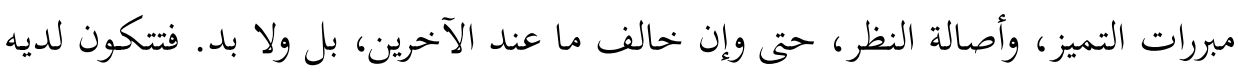

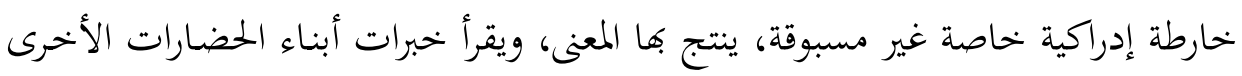

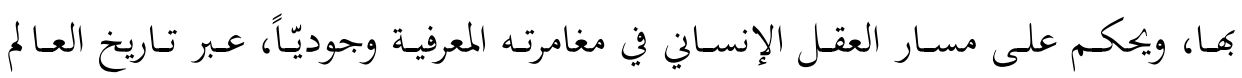
الطويل.

فالنموذج آلية جيدة ومركبة للإحاطة بمعظم جوانب الواقع؛ ظاهره وباطنه، في جزئيته

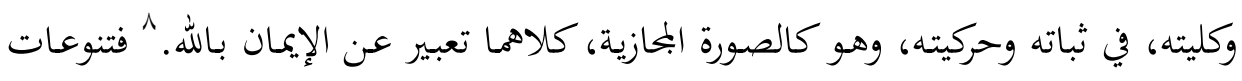
الوقائع وتشعباتها، لا يفيد تباعدها ودخوها في مضمارات تحرك عبثية، وإنما بينها وشائج

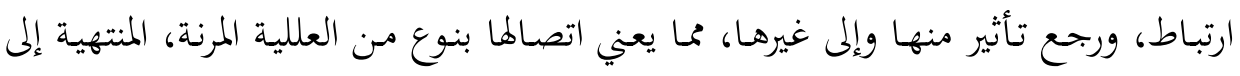

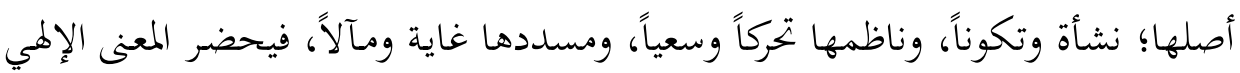

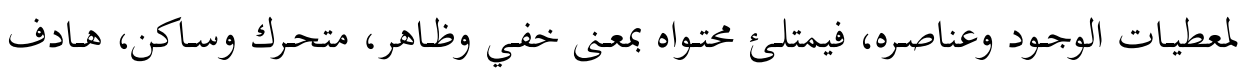
وحر، خاصة ما له علاقة بالإنسان.

والملاحِظظ لما ستناه، يدرِك أن فيلسوفنا إزاء عمليتين متـدابحتين، تستدعى إحـداهما

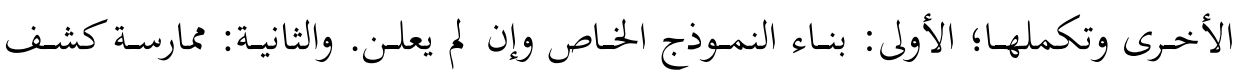

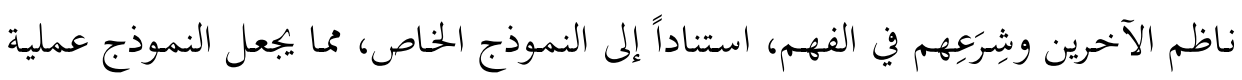

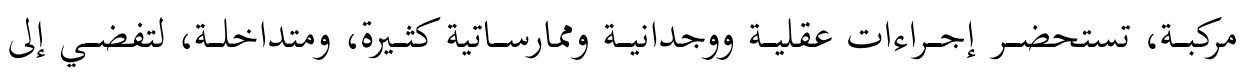

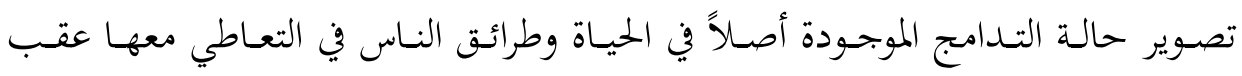

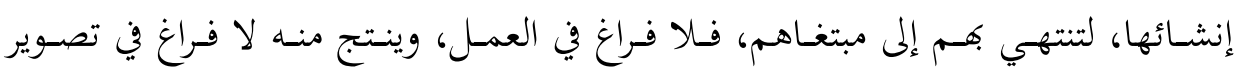

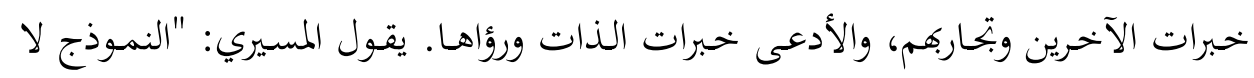

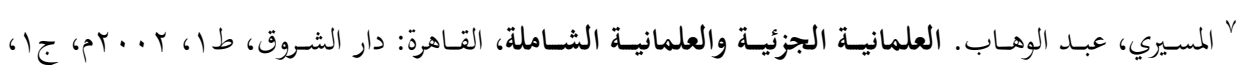

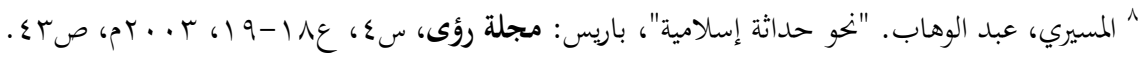




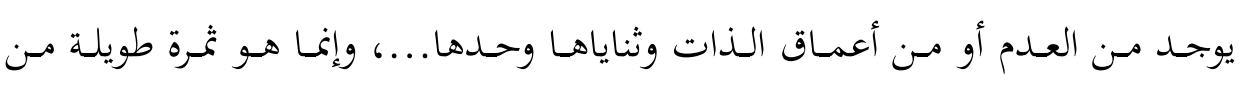

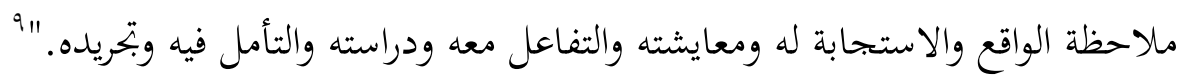
إن واقـع المسـيري، وإن تغـرب عنـه مـدّة، هـو المجتمـع المصـري بمختلـف تداعياتـه

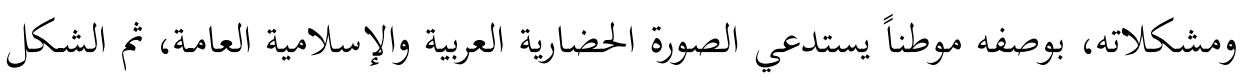

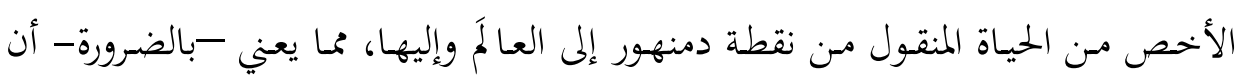

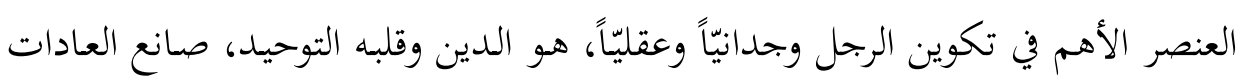

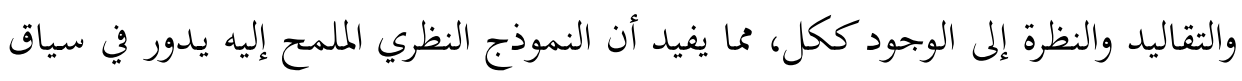

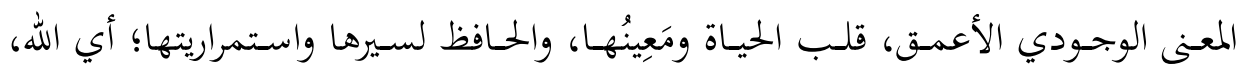

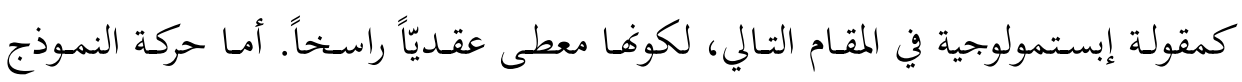

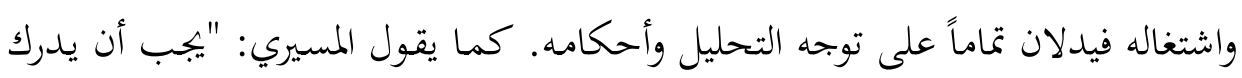

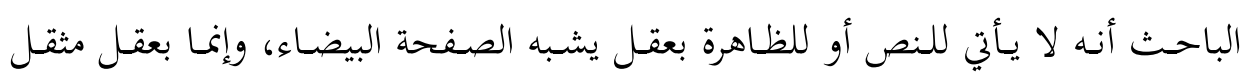
بالإشكاليات والأنماط والتساؤلات، عقل له مسلماته الكلية والنهائية." ·ل وقـــ يتـوارد إلى رُوع القـارئ سؤال مفــاده: مـا مسـلمات المسـيري الكُليـة والنهائيـة؟ فيجاب عن المطروح بالإحالة إلى مصدرية وعي فيلسوفنا، ومنبع رؤيته الكونية: "النموذج رؤج

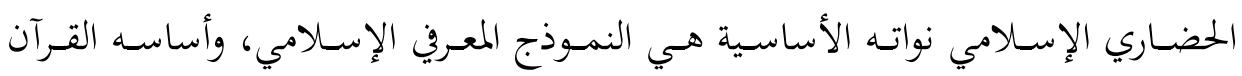

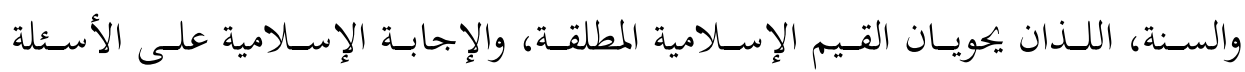
النهائية." "ال ولا عيب في تبني أرضية معرفية ترتكز على معطيات عقدية نابعة من مرجعية الإسية

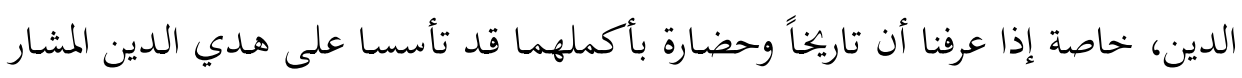

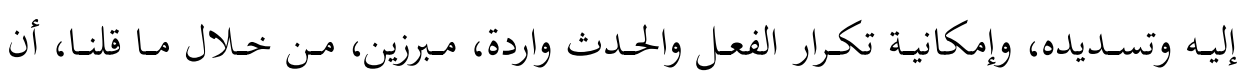
التوحيدية عمق نموذج المسيري المعرفي ومحركه، فيتولد الاجتهاد والإبداع معاً.

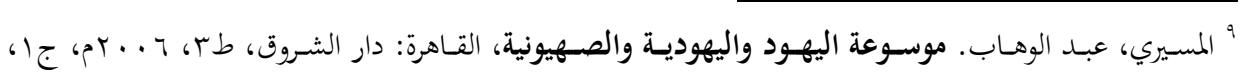
صالr.

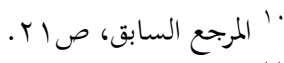

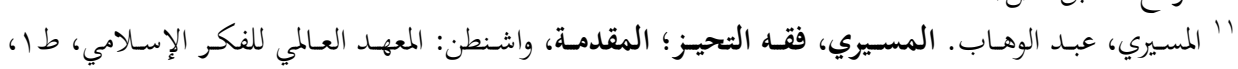


المنهج المعري التوحيدي عند عبد الوهاب المسيري: مدنل إلى الإبستمولوجيا التوحيدية الحاج بن أحمنة دواق Y. تشعب النموذج، وتراوحه بين الإضمار والإعلان، وتنصبه خريطة للإدراك

والفهه:

ويزداد التحليل رسوخاً ووضوحاً، إذا عمدنا إلى بيان النموذج على أساس أنه شبكة

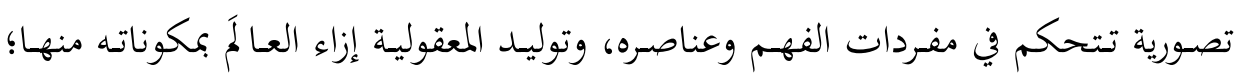

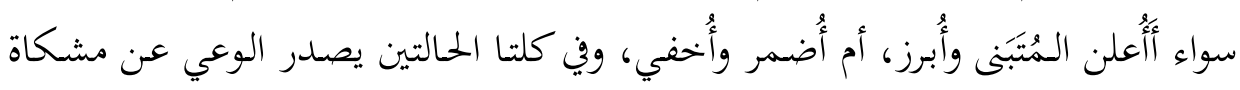
نظرية وتصورية، تحفظ للوعي تحركه المتوازن قبالة الظواهر . يقول المسيري: "كلمة نموذج كما أستخدمها هي الفكرة المحردة والمحورية في عمل ما والتي تتجاوز العمل ولكنها كامنة فيه ويف كل أجزائه، تمنحه وحدته الأساسية وتربط بين عناصره المختلفة."

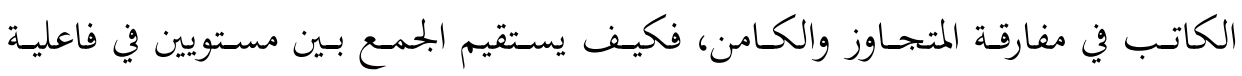
النسق وضعاً ورفعاً؟ يظهر ارتفاع التناقض بالتسليم بأن لكل مفكر معتقداته ومسبقات

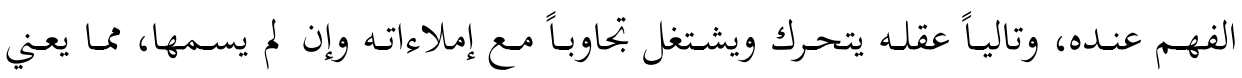
الحضور تسليماً، والتجاوز بعدم إعلاكها وإسفارها، في كل ثنايا البحوث والأعمال.

وهنا أزعم أن المسـيري تبنى التوحيدية بهذا الشكل، فالوعي بهـا حاضر في أعماقه،

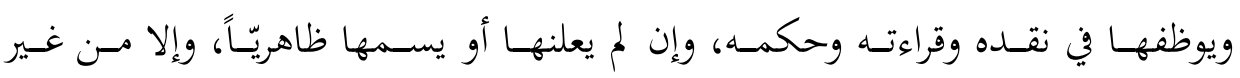

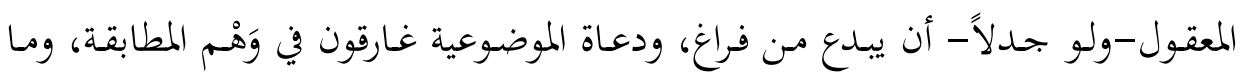
أبسطه من تصوير! إذ "التلقي الموضوعي المادي للمعلومات يؤدي إلى تراكم المعلومات الصماء التي لا تقول شيئاً، والتي تخفي كثيراً مـن الرؤى والتضمينات الفلسفية والمعرفية

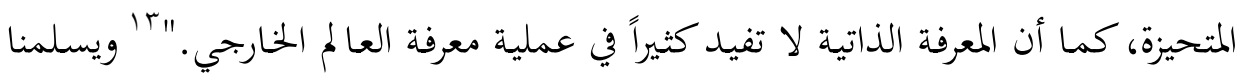

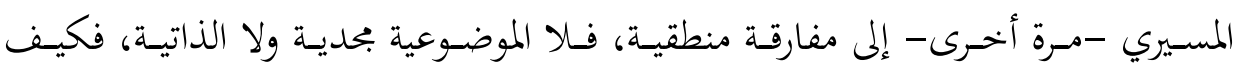
نعرف؟ يطرح المسيري التفسيرية بوصفها بديالًا للذاتية والموضوعية العاجزتين على استكناه الواقع، وتعرّف صسيرورته، "وعلى ذلك، فِإن معيارنـا لا ينبغي أن يكـون الدقـة أو كثـرة المعلومات، أو مطابقة معلوماتنا للواقع، وإنما المقدرة التفسيرية... أكثر تفسيرية... أو أقل دئل

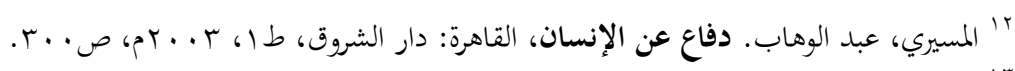

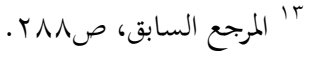


تفسيرية، "أ بزعم أن الواقع ليس فيه ما يشرحه، أو يطابقه، كما أنه غير خحال مما يدل

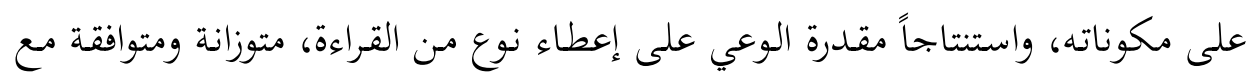
توجهات الأشياء وسيرها، مولّدة القبول والرضا، وإن لم يترجم ذلك إلى أشكال إجرائية.

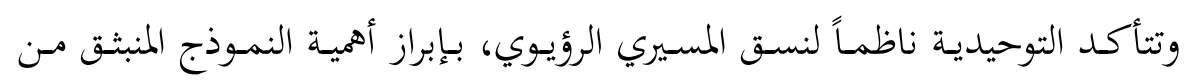

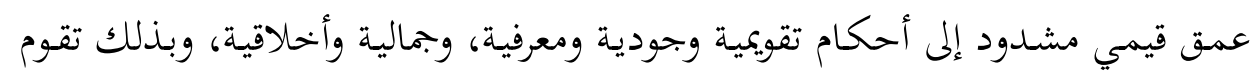

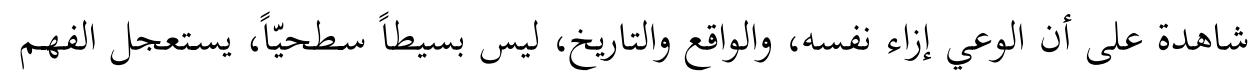

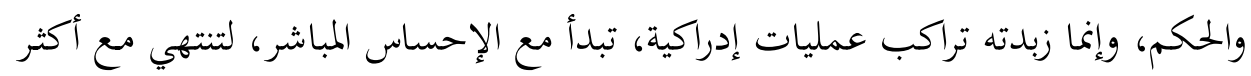

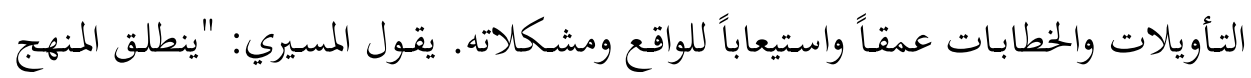

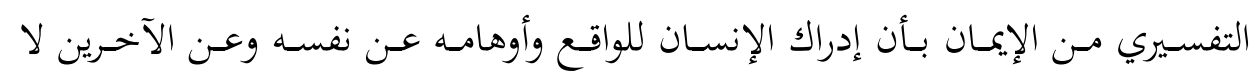

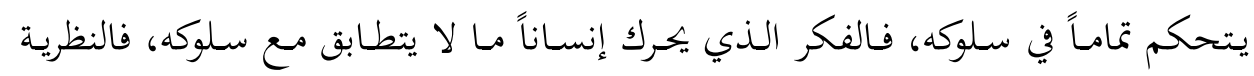

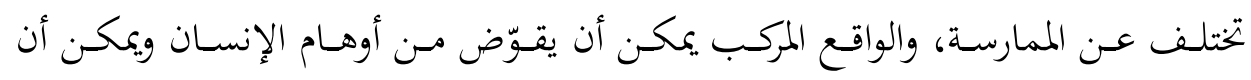

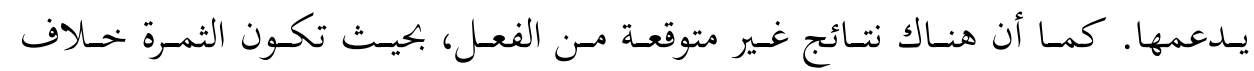
القصد. 'ا فما نحسبه خطية في الفهم هو أحوال اختزال واستعجال يمارسهما البشر إزاء

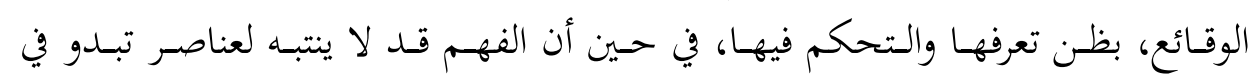

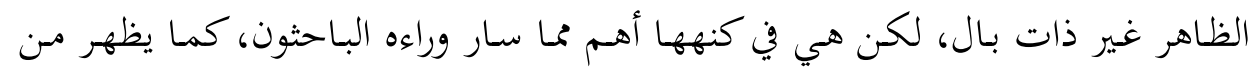

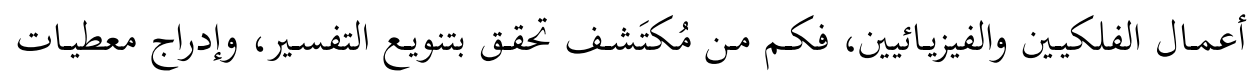

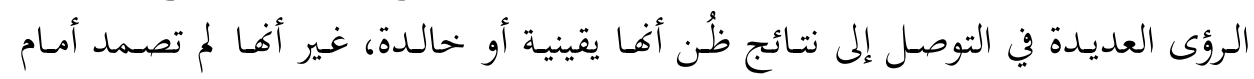

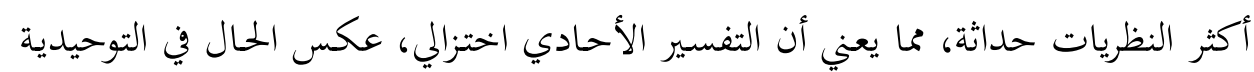

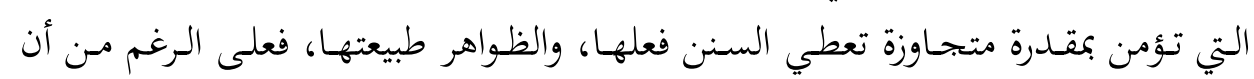
الأرض واحدة وتسقى بماء واحد، إلا أن نتاجها متنوع.

\section{ץ. فاعلية التوحيد، ونمط المعرفة الناشئة منه:}

إذن؛ ميل الوعي إلى التعامل مهع الكـون بنوع مـن التحرر المنضبط، يجعله أركز في

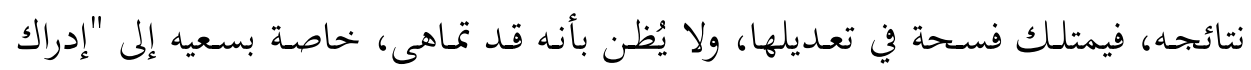




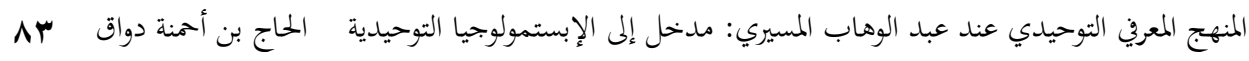
الوحدة الكامنة وراء التنوع." "ال وهنا نلتقي مع روح التوحيدية وظلها إبستولوجيّاً، عملاًا

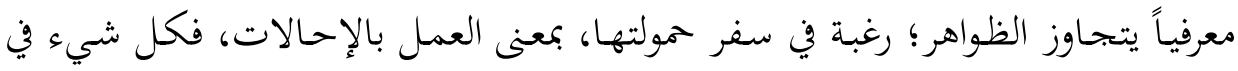

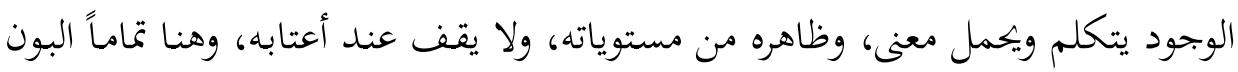

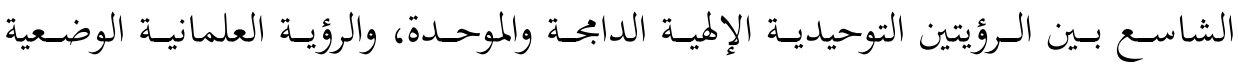

الفاصلة.

فنحن إزاء وصال في تعالج مـع فصال؛وعي يقرأ العالم على أسـاس أنه وحـدة، وإن

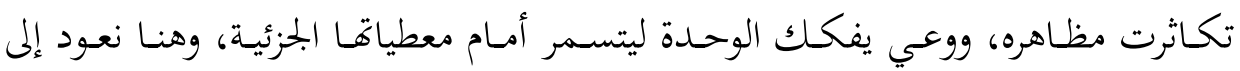
إشـكال جـوهري عرفه العقـل البشـري منـذ أيامـه الأولى؛ هـل العلـم كليـات تـدرج تحتهـا

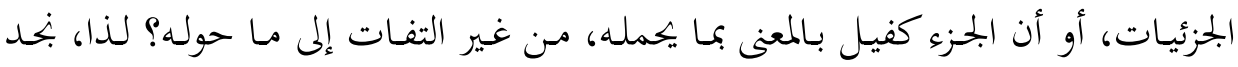

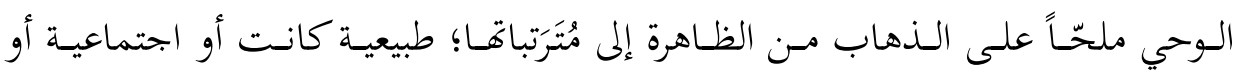

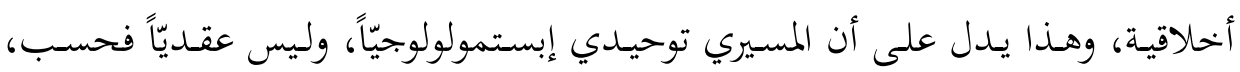
وأن الوعي التوحيدي تراوح بين الخالق والمخلوق؛ "فالله سبحانه ليس كمثله شيء، فهو غياب إمبريقي كامل، ولا يمكن أن يدرك بالحواس، ولكنه في الوقت نفسه، أقرب إلينا من

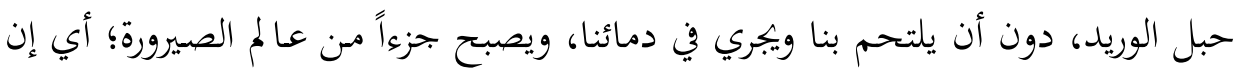

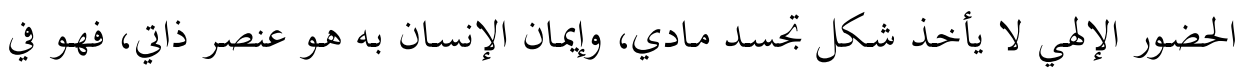

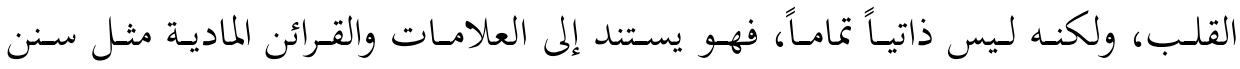
| الطبيعة.

ففاعلية التوحيد معرفيّاً تكمن في أنه يستحضر الله -سبحانه- مقولةً تفسيريةً تعمل

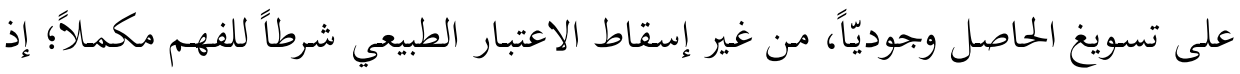

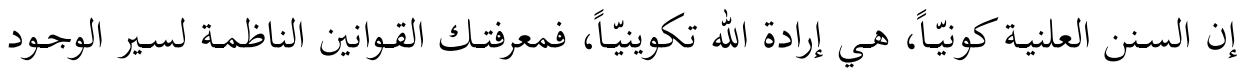
وتحركه، اطّلاعُكك على مراد القدرة الإلهية، من غير بتحسيد ولا مفارقة، بل المحايثة يصنعها إرها

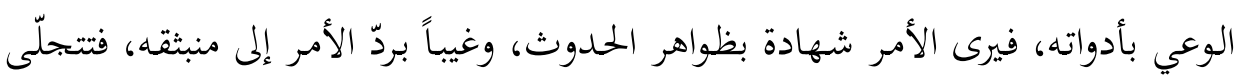

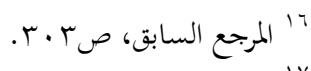

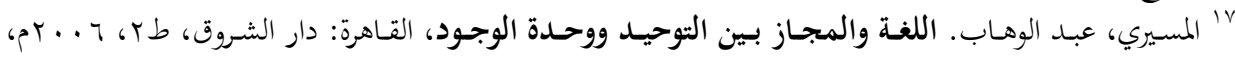




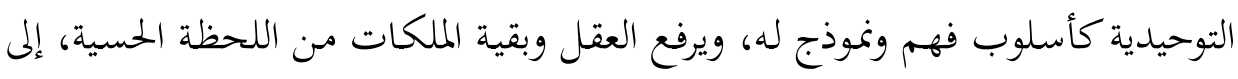

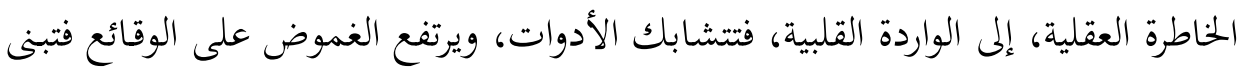

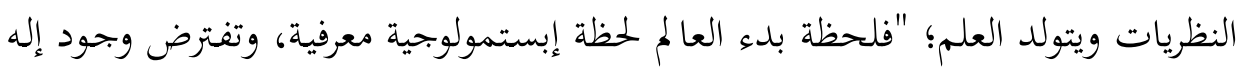

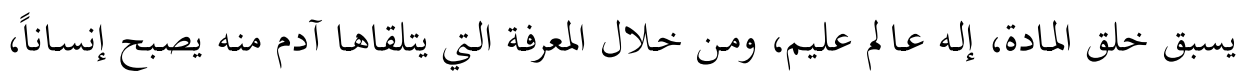

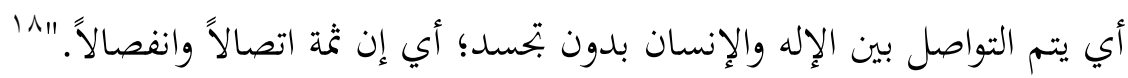

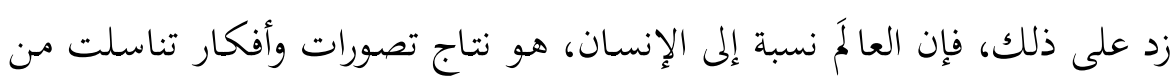

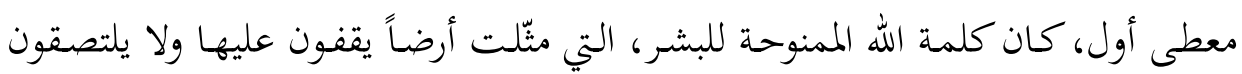

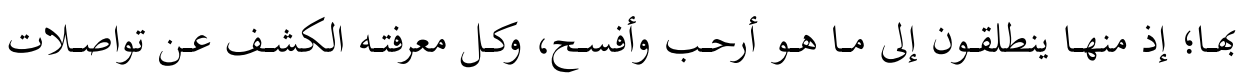

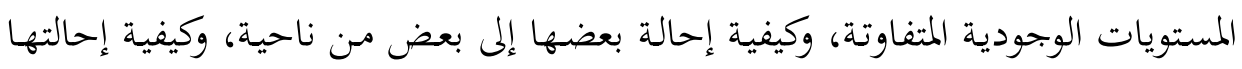

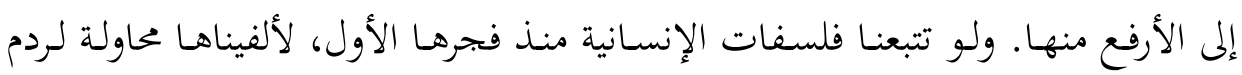

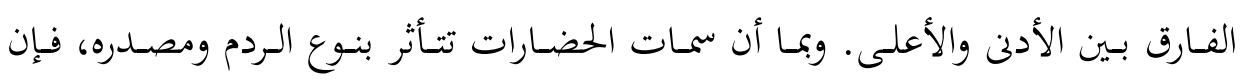

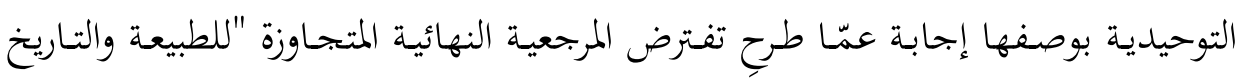

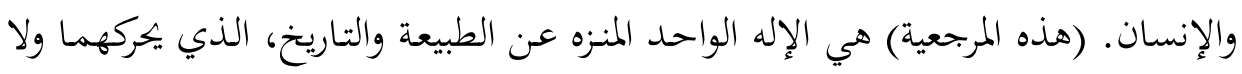

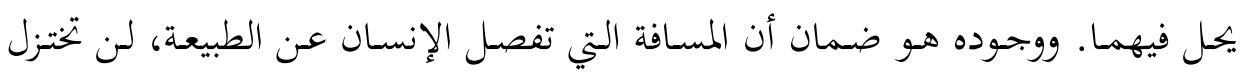

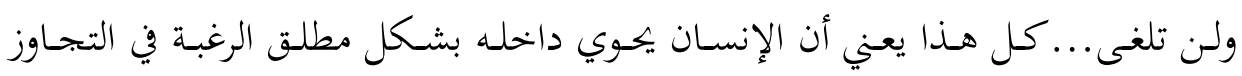

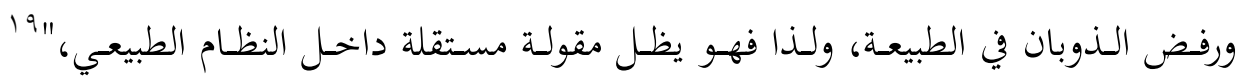
يمارس التعقل بنوع من الفصل والوصل في آن.

\section{ع ـ النموذج التوحيدي ومعياريته التصديقية:}

وهنا نتذكر أكثر تفسيرية وأقلها، مما يعني أن التوحيدية إبستمولوجيّاً تؤمن بالحقيقة

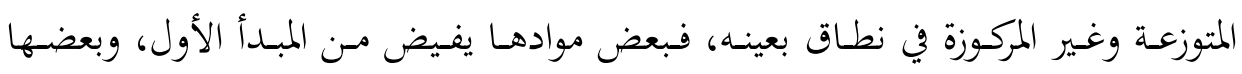

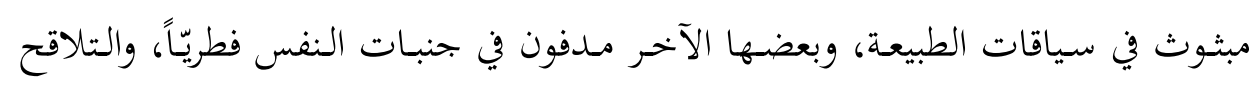

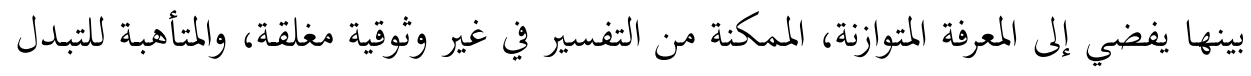

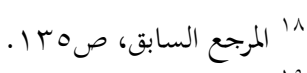

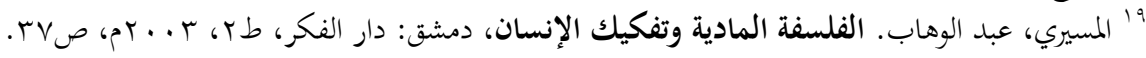




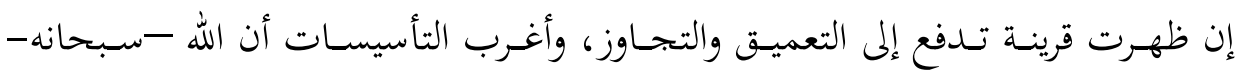

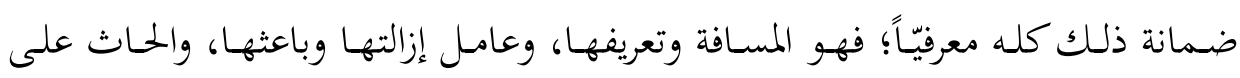

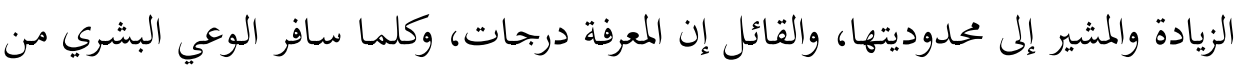

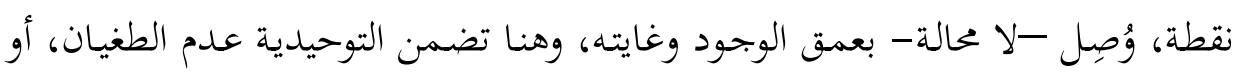
لا تزعم بلوغ نقطة التحكم الإمبريالية، بزعم النهائية المطلقة، كما درجت النظم العلمانية

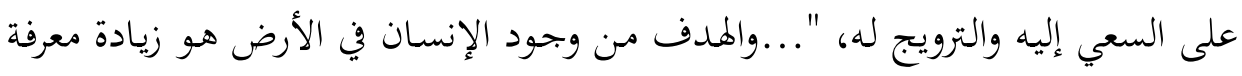
قوانين الحركة والطبيعة البشرية والهيمنة عليها من خلال التقدم المستمر الذي لا ينتهي،

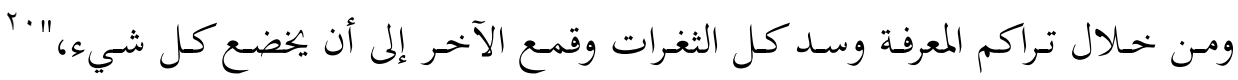

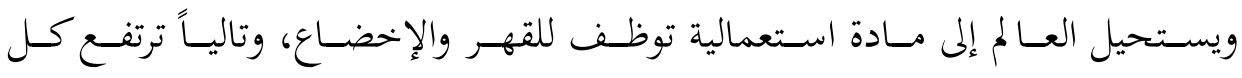
الخصوصيات، فلا غاية للسعي، سوى السيطرة على كل شيء، ولحظة السيطرة لحظة

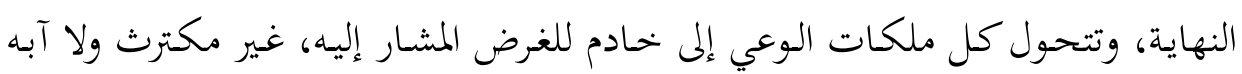
بنطاقات الخصوصية، على أساس أن الكون لا خصوصية فيه ولا تفرد؛ لأن مدار الحئ الحركة

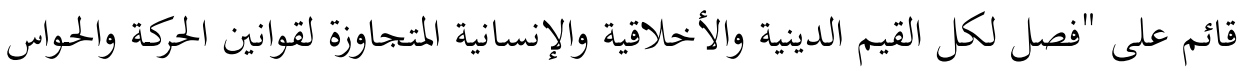

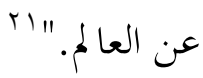

وكل الطموح النظري للتوحيدية؛ العمل على الدمج بين مستويات الوجود، في إطار

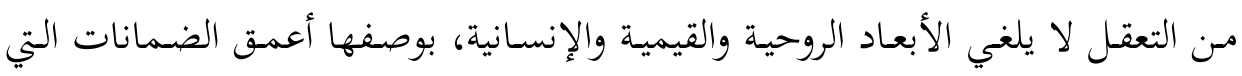

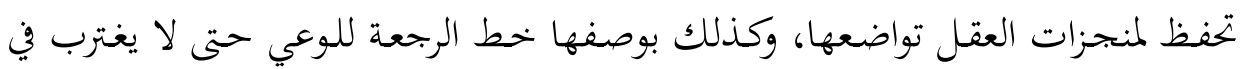
خضم العنفوان الإنساني فيتلافى الطغيان، كمآل طبيعي للفصل بين المستويات الوجودية.

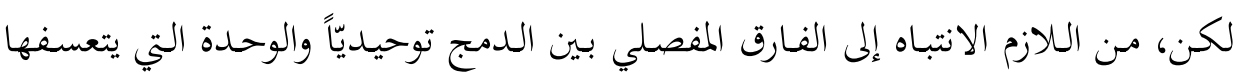

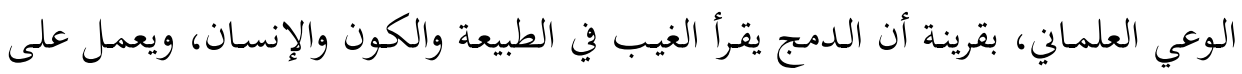

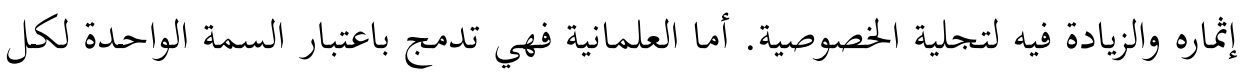

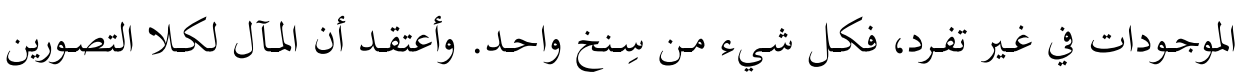
واضح تماماً.

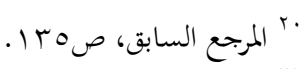

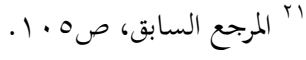


فالتوحيديـة -حسبـ التحليـل السـابق - نمـوذج معـرفي بــيل، يستحضـر الطبيعي

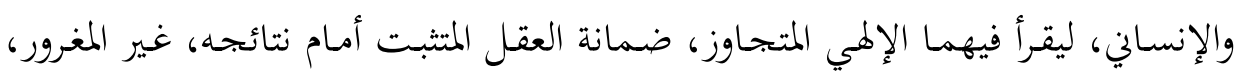
الذي يكتشف التوازن في كل شيء، ليحيل قواه الإدراكية إلى مبلغ اللطف في الأشياء،

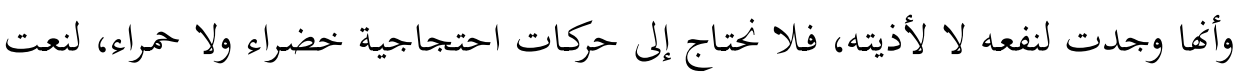

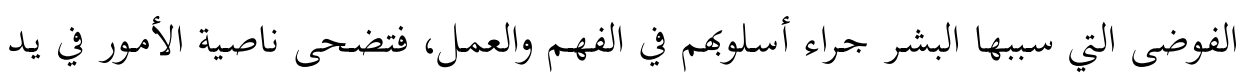

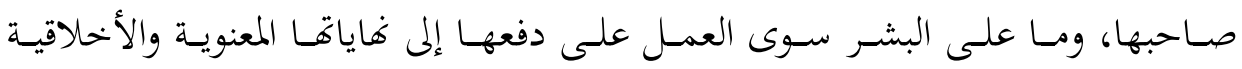

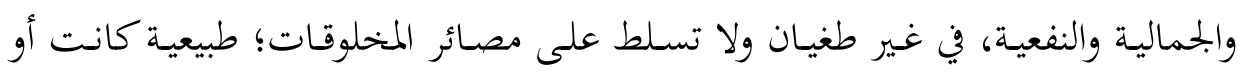
بشرية.

إن من وظيفة الإبستمولوجيا تصحيح مسار العلم والمعرفة، حتى في تطبيقاقما، فلا يضير أن يدعو العلم إلى أخلاقية الفهم والممارسة ومعنويتهما. يقول فيلسوف الإست التوحيدية،

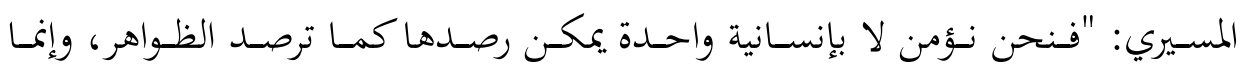

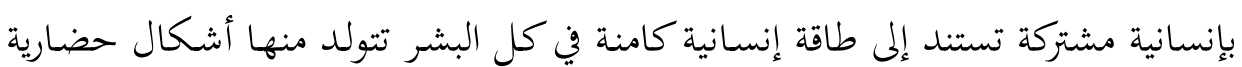

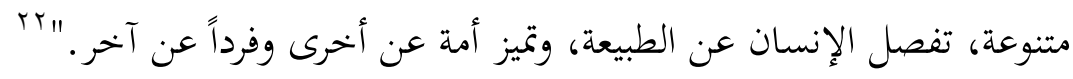

ولو افترضـنا مقـابلاً للتوحيديـة في التقريرات السـابقة، لكانـت العلمانيـة، التي تعتقــ

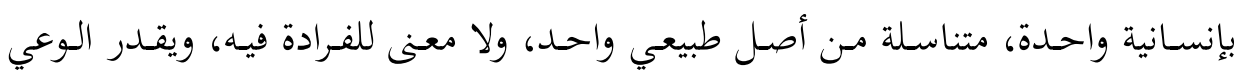

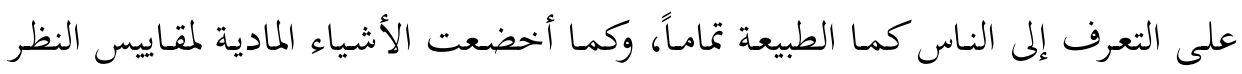

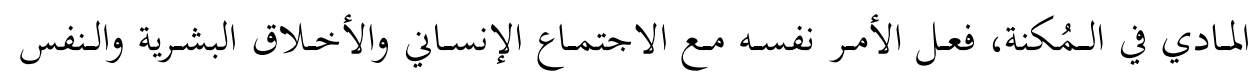

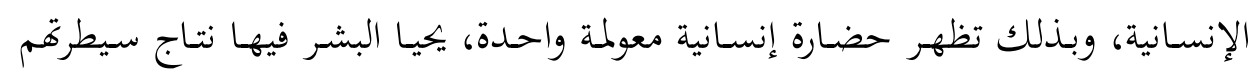
على الطبيعة والتاريخ، في شكل رتيب دائري، من نقطة يبدأ وإليها يؤول.

ثالثاً: المنهج المعرفي التوحيدي: المنبثق والقواعد

رأينا سابقاً أن التوحيدية ليست إطاراً عقديّاً يسلِّم المؤمن به وبمضامينه وحسب، بل هي سياق تصوري وإطـار إبستمولوجي، مؤهل لأن يشكل البـديل بالنسبة إلى نظريات 
المعرفة الكلاسيكية، كما يمكن أن تتحول التوحيدية من الوظيفة الإنتاجية للمعنى، إلى

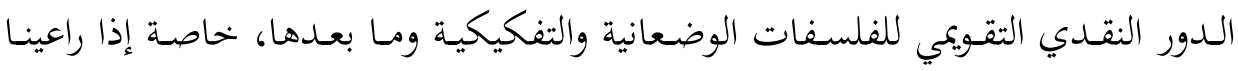
العمق الإنساني والأخلاقي الذي تتمتع به التوحيدية، فليس من شأن الإنسان أن يفهم

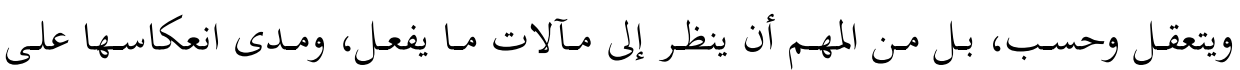

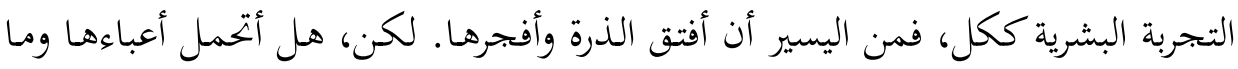

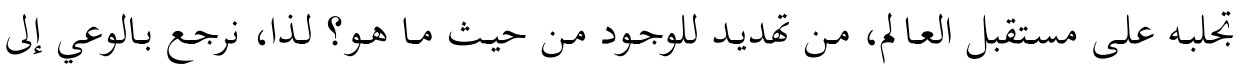

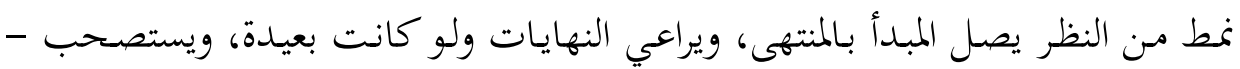

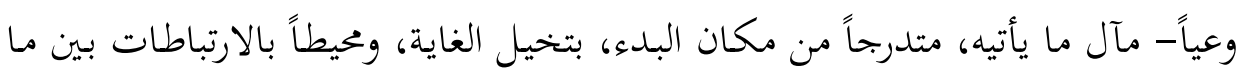

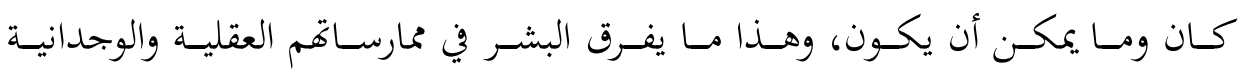

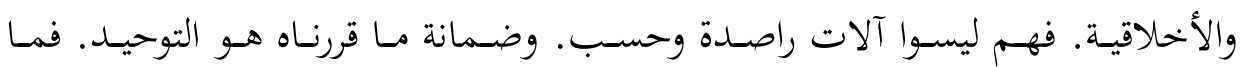

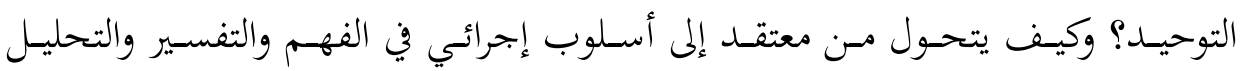
والتصديق والحمى؟ وتحب

\section{ا ـ التوحيد؛ الدلالة والمقولة:}

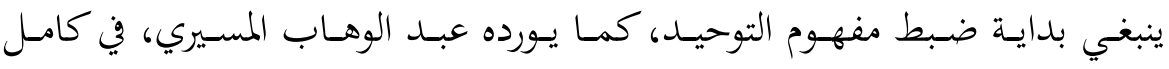

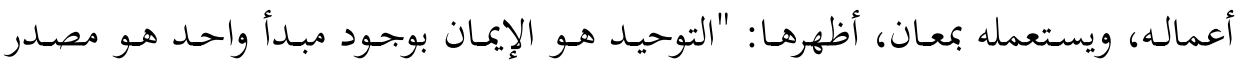
وحدة العالم، وهو الإله. وهذا الإله خلق الإنسان والطبيعة والتاريخ، وهو الذي يحركهم

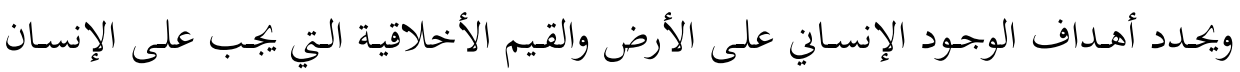

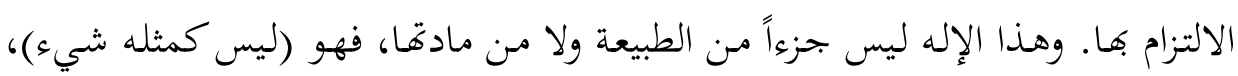

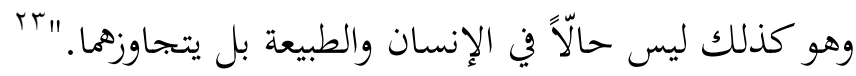

مـا أوردنـاه يجيلنـا إلى عمق معرفي خحاص ونوعي في تصوير التوحيد وعياً، فالتوحيد

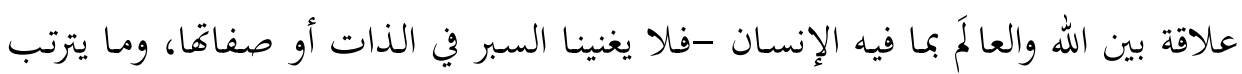
من مشكلات عقدية بحالها غير الإبستمولوجيا- علاقة توجب النظر إلى الكون على أنه

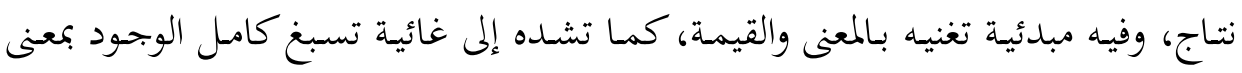




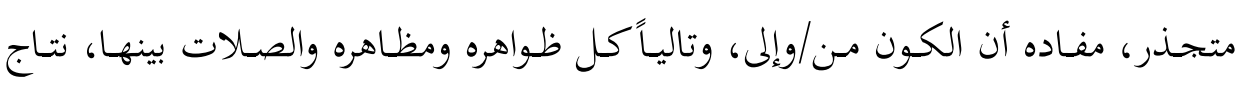

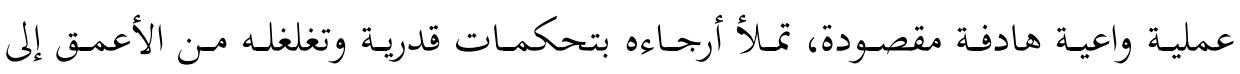

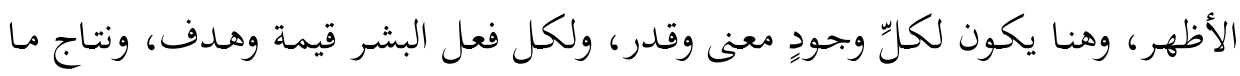

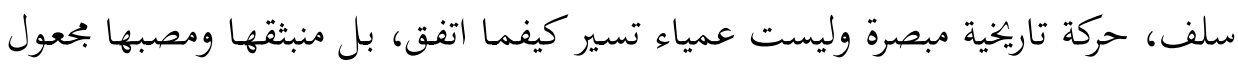
جعلاً، وعلى البشر الإفادة من الوجود بوصفه وقوداً لتلك الحركة وحاثاً عليها.

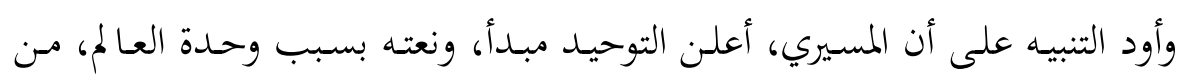

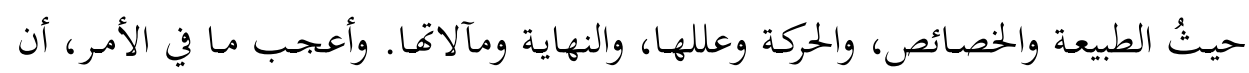

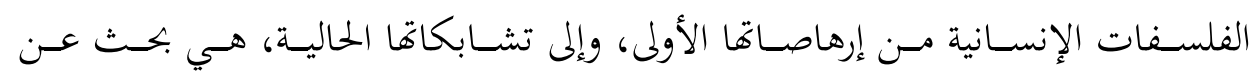

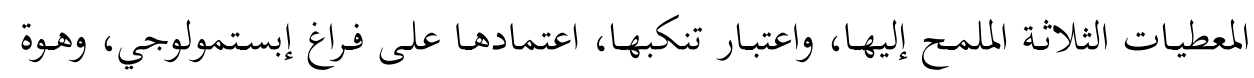

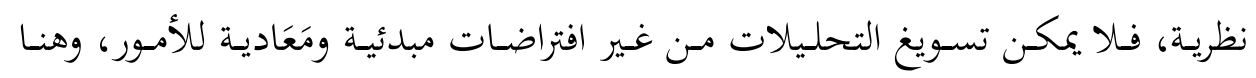

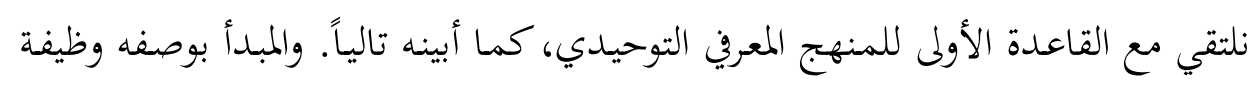

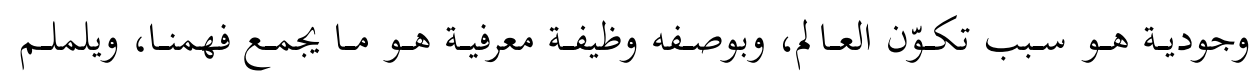

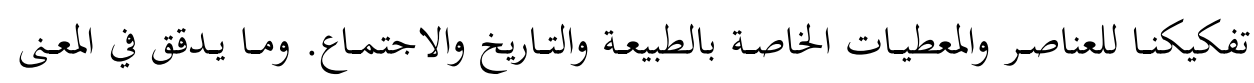

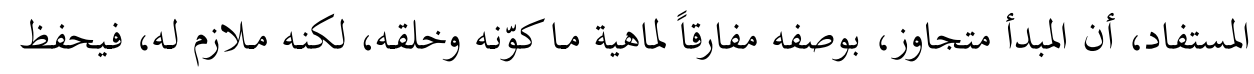

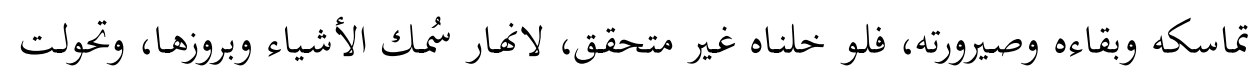

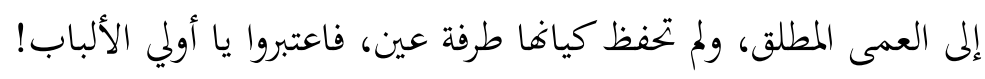

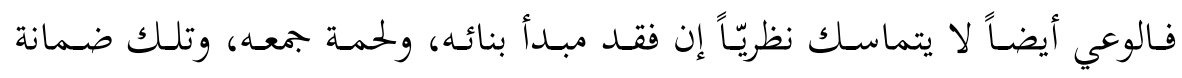

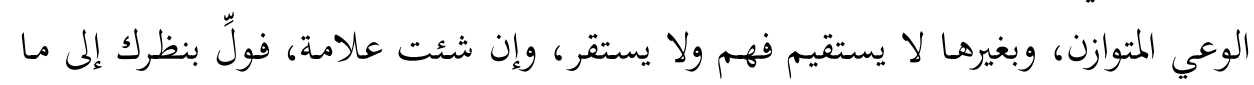

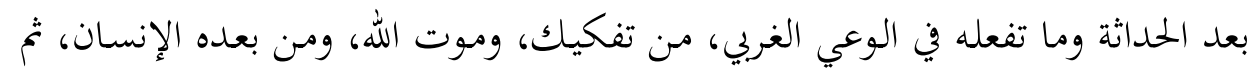

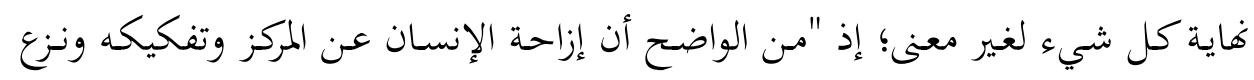

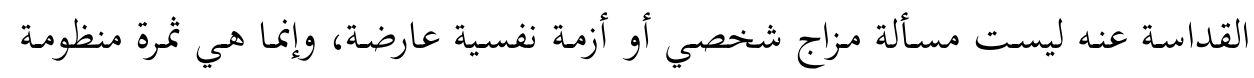

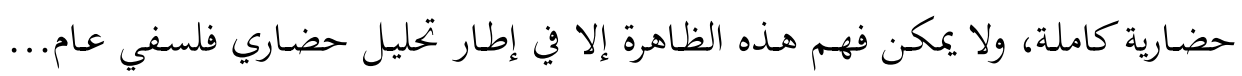

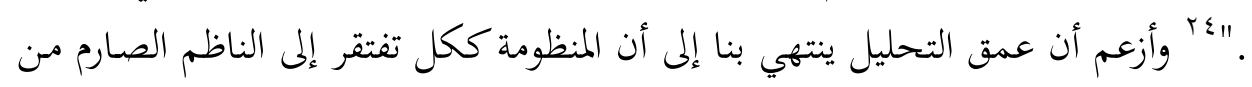

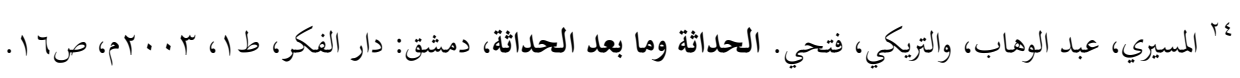


المنهج المعري التوحيدي عند عبد الوهاب المسيري: مدخل إلى الإبستمولوجيا التوحيدية الحاج بن أحمنة دواق 99 خارجها، فما تشكل من الداخل تضيع تسديداته عن نفسه بداية، ثم عما يتكلم فيه

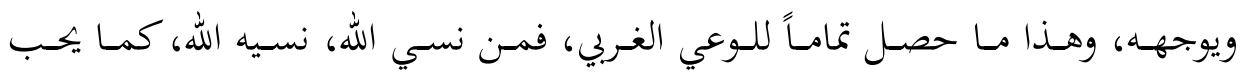

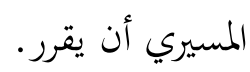

وتتأكد وظائف التوحيدية، إذا أخذنا مآلها في الاعتبار -وهنا أطبق منطق التوحيدية

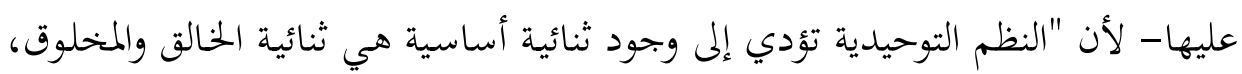
وبناء على هذه الثنائية وعلى هدي ما يرسله الخالق من رسالات تنشأ ثنائية أخرى هي لني

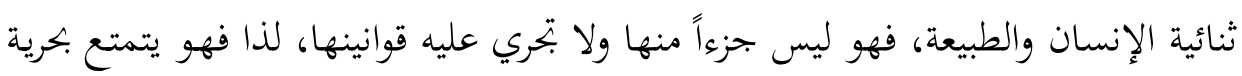

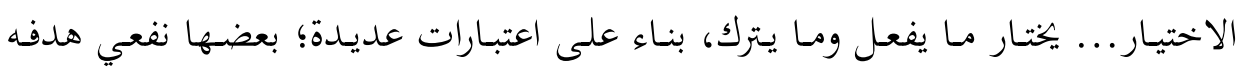
تحقيـق منـافع مباشـرة غالبـا ماديـة، كمـا أن بعضـها اعتبـارات لا ماديـة (إيمانيـة أخحلاقيـة)

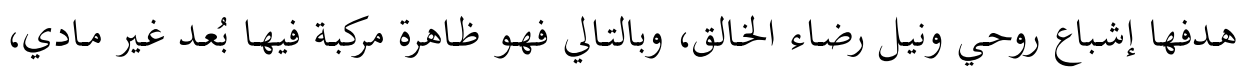

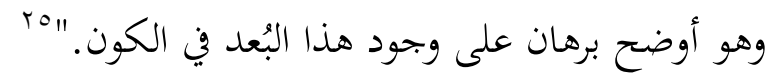

وعليه، يتعمق وعي الإنسان إبستمولوجيّاً، إزاء ذاته والعالم، عندما يدرك أن الكون

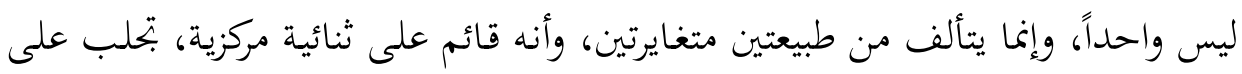

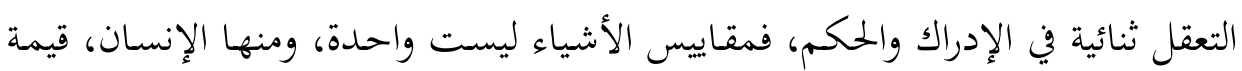

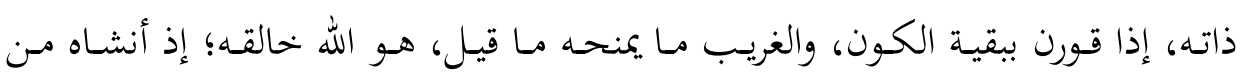
طبيعة متجاوزة ومحايثة في الآن عينه، جسمه أرضي، وقيمه وأخلاقه ومعاملاته وعلاقاته،

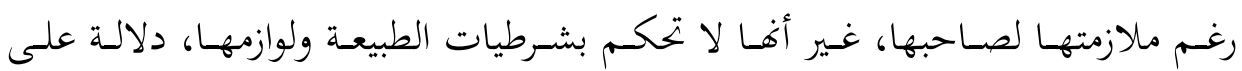

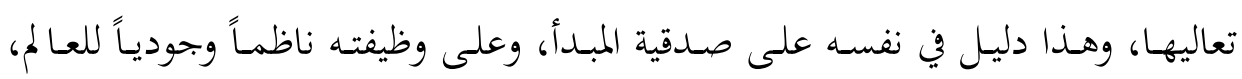

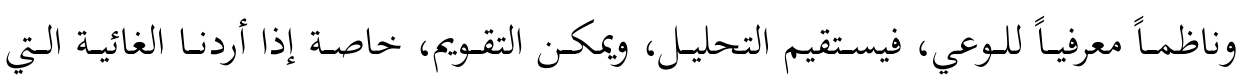

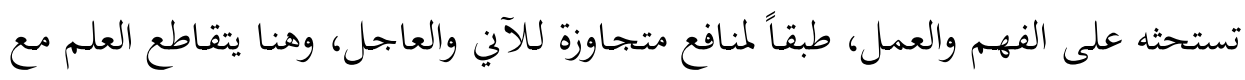
الأخلاق، فلا يجاوزها كما لا يتنكبها ويضعها شرطاً في الاعتبار الأدائي لممارساته. إذن؛ لا الوجود ولا الوعي يعملان بغير مركز "هو المقر الثابت الذي تتشعب منه الفروع... مطلق مكتف بذاته، لا ينسب لغيره، واجب الوجود، لا يمكن أن تقوم رؤية 


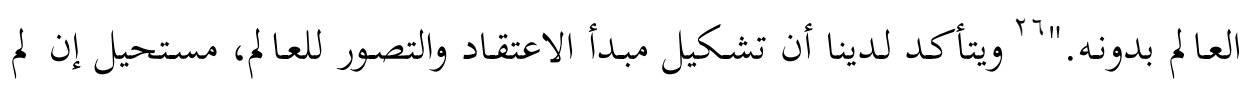

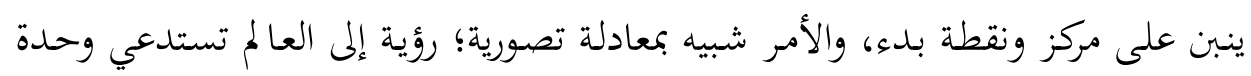

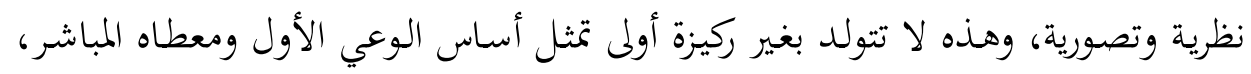

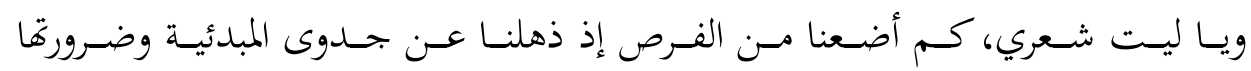

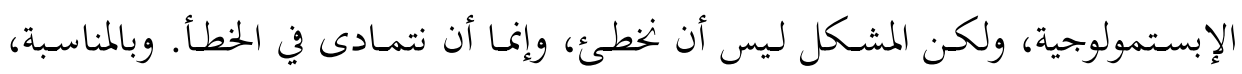

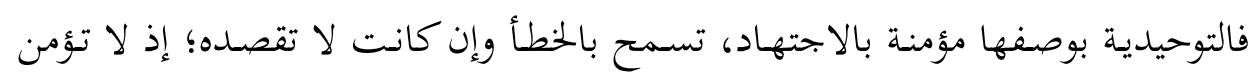

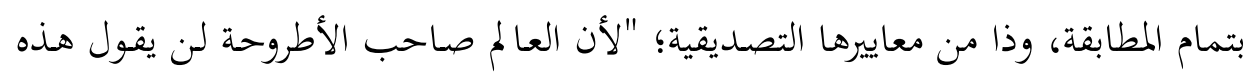

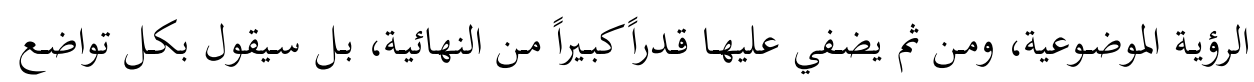

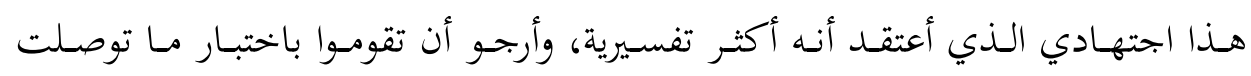
إليه."

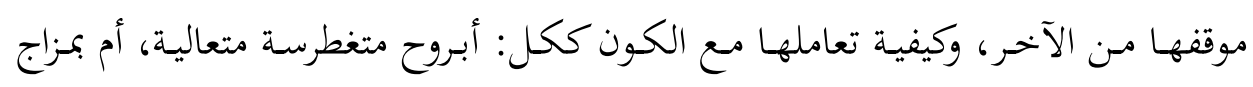

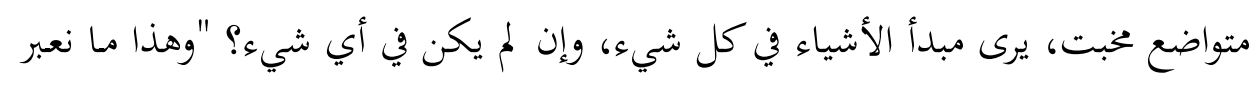

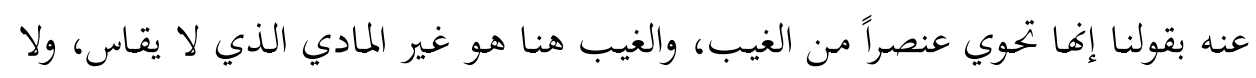

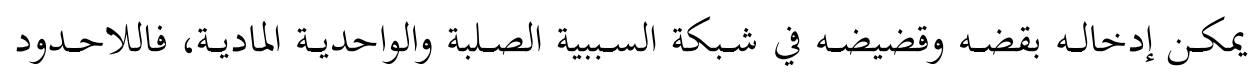

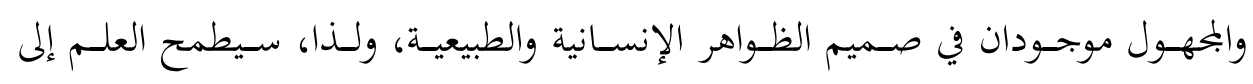

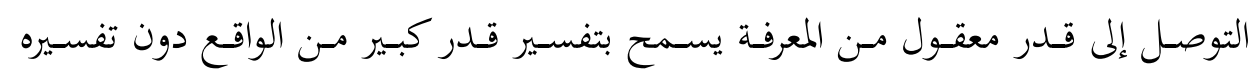
كله.

وتتقد فاعلية التوحيدية باعتبار حمولتها النظرية، التي تصور العالم بغير إخلال، وتولّد

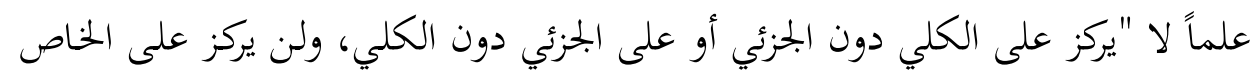

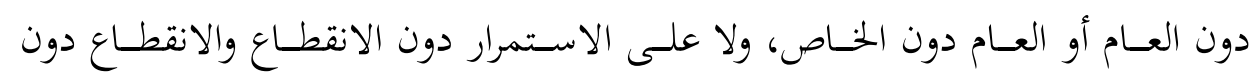

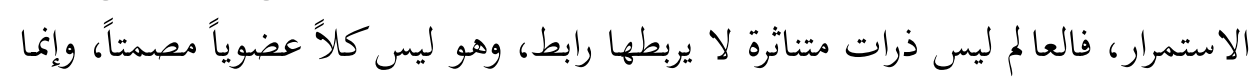

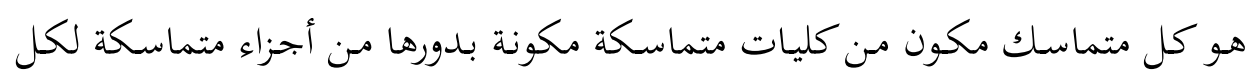

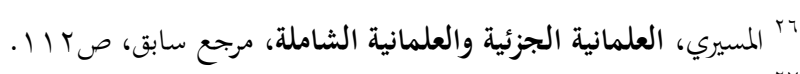

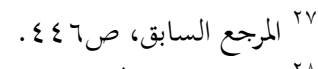

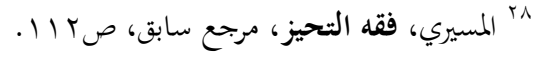


9) المنهج المعرفي التوحيدي عند عبد الوهاب المسيري: مدخل إلى الإبستمولوجيا التوحيدية الحاج بن أحمنة دواق

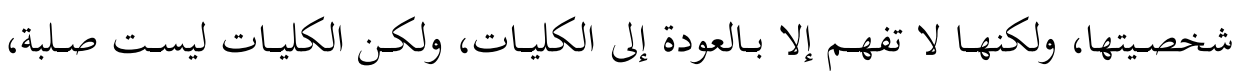

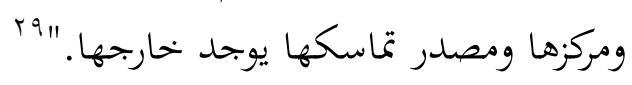

تجمَّع لدينا من التأسيس للتوحيدية إطاراً ومعنى، ما يغني لاستجماع قواعد المنهج

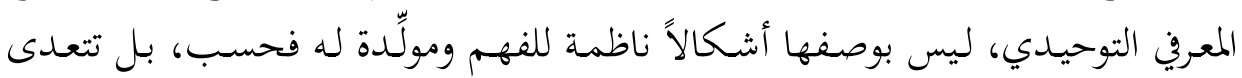

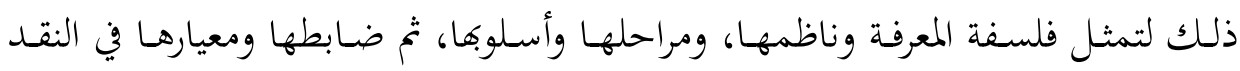
والتقويم. فالقواعد تستعمل للإنشاء والتأسيس، ثم الفهم والتعقل، والتحليل والتفسير، ثم

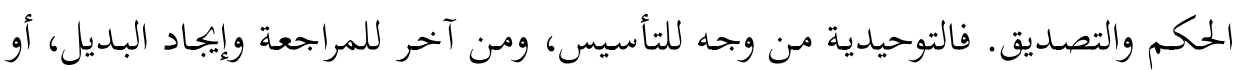

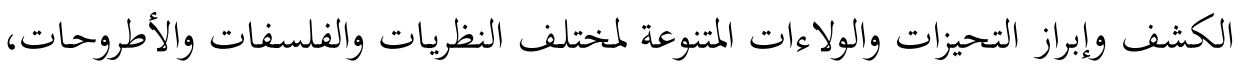

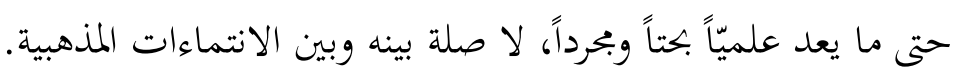

ومن خهلال قراءاتي بمحمل مـا كتبه المسـيري وألّفه، فإن التوحيدية عنده، تتوزع تبعاً لأربعة معالم ونواظم، تنظم الوعي إزاء نفسه ومضامينه، كما بتحاه العالم بجميع مكوناته،

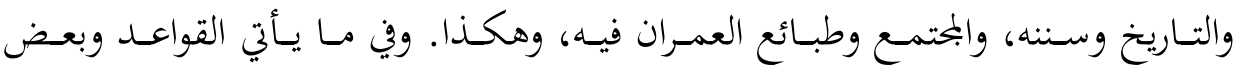
المؤشرات التفسيرية عليها:

\section{القاعدة الأولى: الوعي بين حدي المبدئية والمَعَادِيَّة، أو من جذور الوعي إلى}

ثماره

تدخل المبدئية والمعادية في كل الظواهر والمعطيات ومولدات الوعي، والوجود في جميع

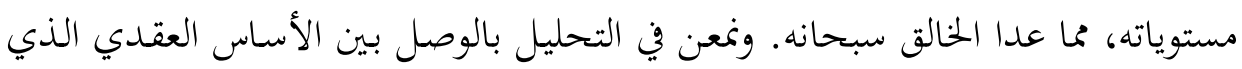

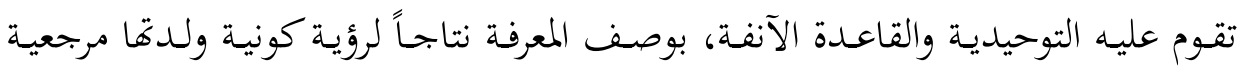

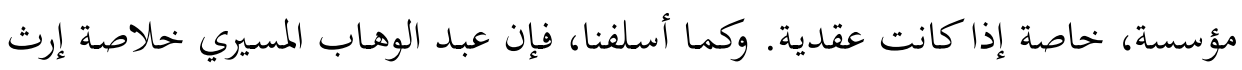
تربوي عميق يعود بجذوره إلى الكتّاب، وإلى الأسرة المصرية المتشبعة بالرؤية والالتنام الديني

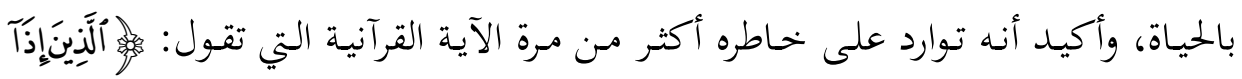

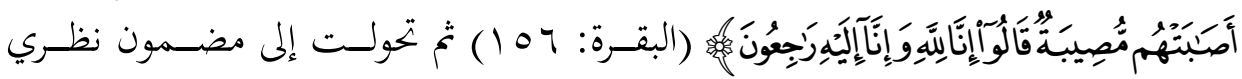
تسرب إلى أعماق عقله، وتالياً صاغ وجدانه توافقاً مع الحقيقة العقدية المستفادة من تلك الك الك 


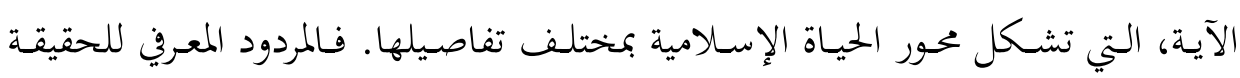
الإيمانية السابقة، هو أن الكيان الإنساني ومحيطه الوجودي بظواهره الكثيرة والمختلفة، بدأ

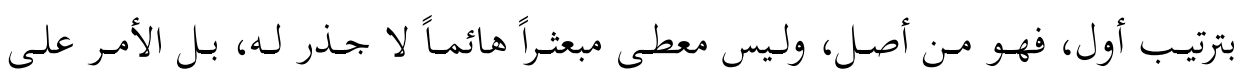

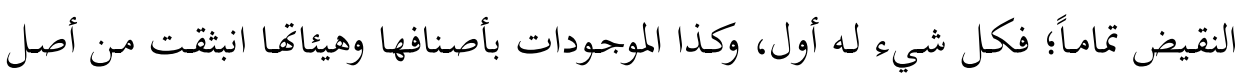

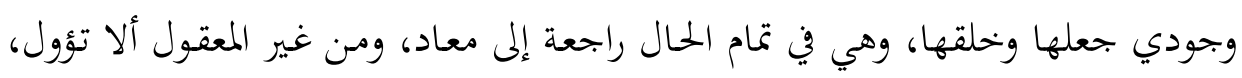

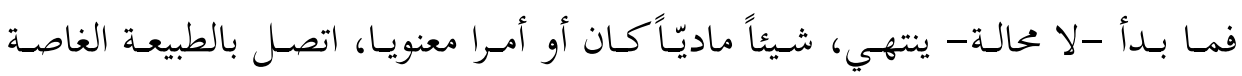

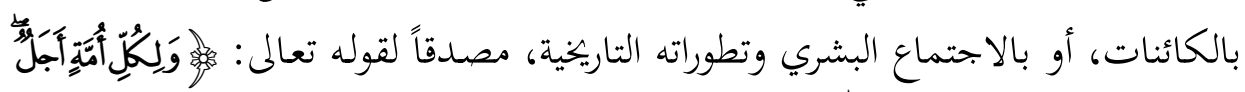

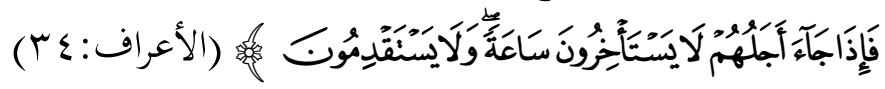

فالفهم إذا ابتحه تلقاء أي شيء ينبغي أن يضعه في حدية إدراك وتصور، ليتمكن من

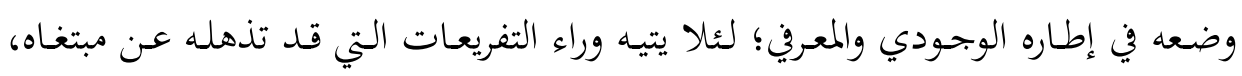

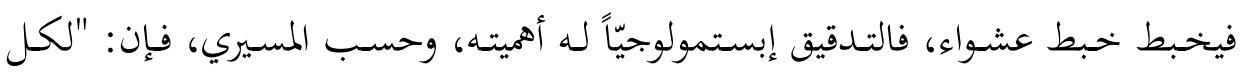

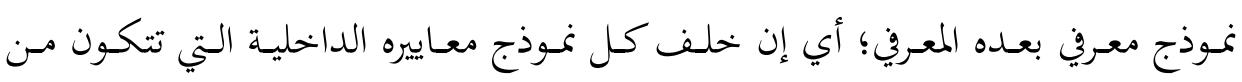

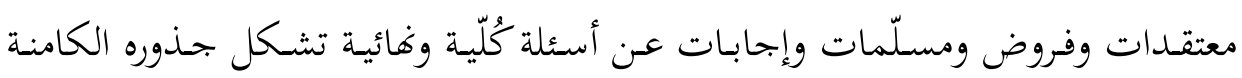

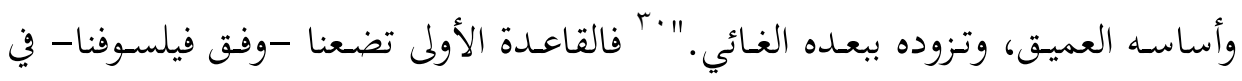
معرض النظر إلى كل ما يقف أمام الوعي في نطاق من المنطلقات والمصبّات، ولا يتخيل فهم بغير مسلّمات وفروض تعد المنطلق له، زيادة على البُعد الغائي الذي يستحث الفهم على التعقل أكثر للاستفادة، والتزود منه لما هو أنفع وأفيد. وأزعم أن كفاءة التوحيدية تكمن في توظيفها على أساس أهفا آلية في الكشف عن

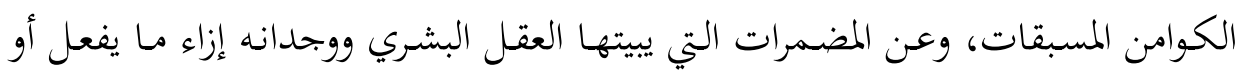

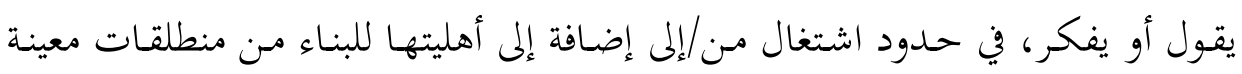
للوصول إلى أهـاف يفترضها. وعليه، إذا شئت تصوراً أبلغ وأركز فـانطلق مـن أنَّ لكل

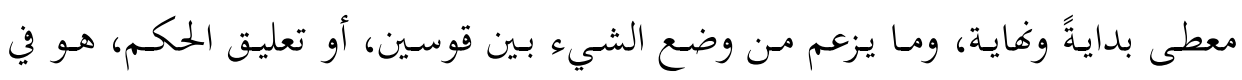

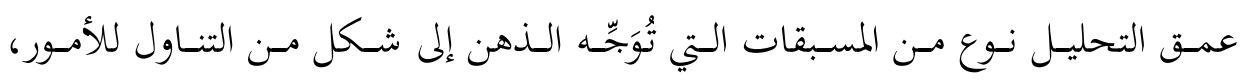




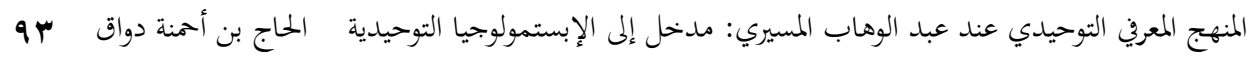

واستنتاجاً لا بدايات من فراغ، كما لا هايات ليست فيها معقولية الغرض والنتيجة. وكلٌّ

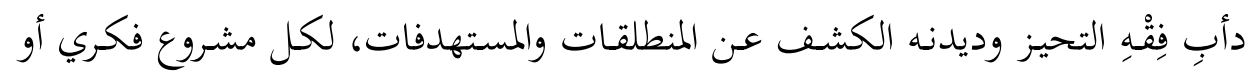

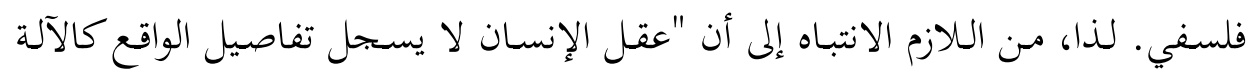

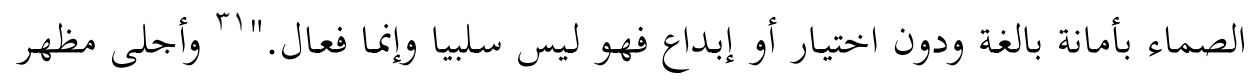

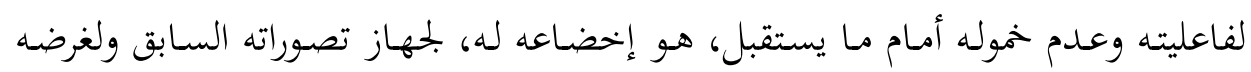

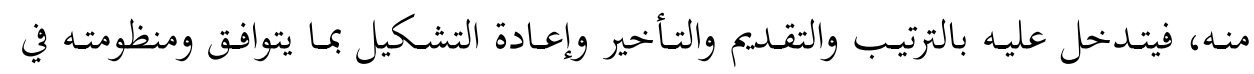

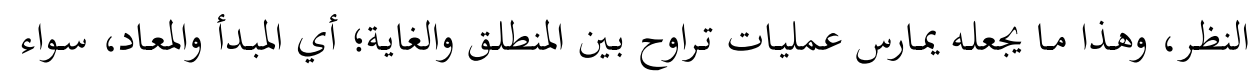

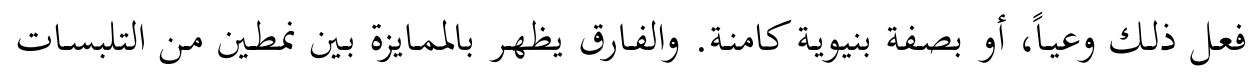

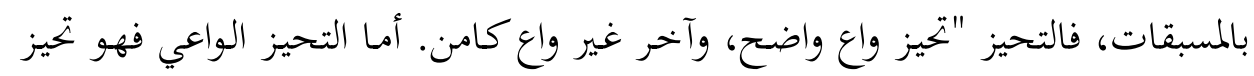

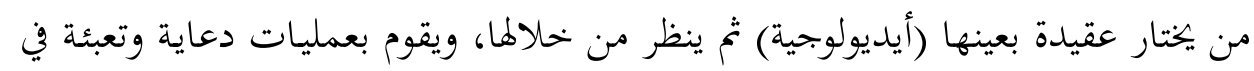
إطارهـا. أمـا التحيز غير الواعي، فهو أن يستبطن الإنسان منظومهة معرفية بكل أولياتها

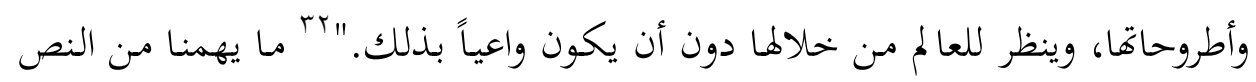

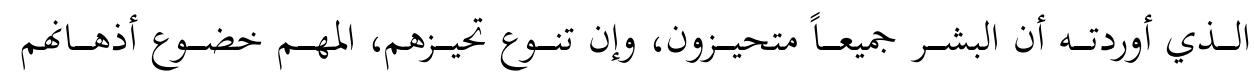

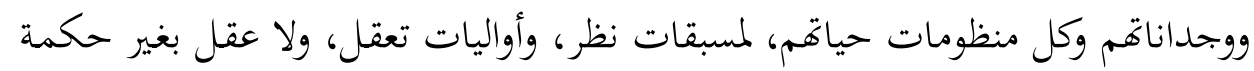

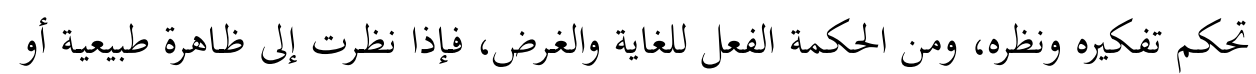

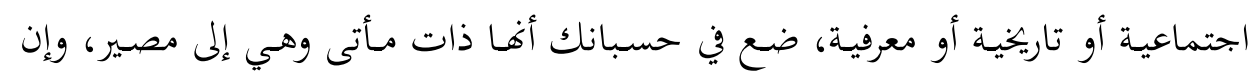
تباين شكل التحليل لكل منها.

الإفصـاح عمـا سـلف تعـوزه الوسيلة الكفؤة القـادرة على ذلك، وليس عـن اللغـة محيص، ومرجع ذلك اعتمادها على البحاز لقطع المسافة الفاصلة بين الدال والمدلول في جميع ميادينه، "فالصور المجازية هي جزء أساسي من عملية الإدراك، وهي بالتالي مرتبطة

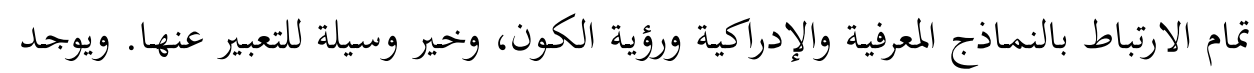

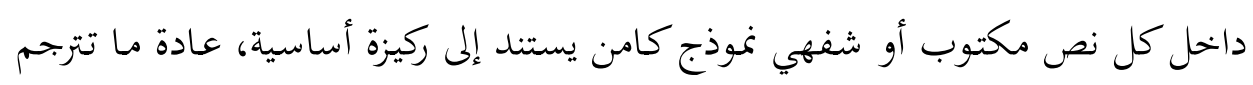
نفسها إلى صورة بحازية، استخدمها صاحبها للتعبير عن النموذج وبالتالي تتضح مرجعيته

$$
\begin{aligned}
& \text { rr المرجع السابق، صrr }
\end{aligned}
$$

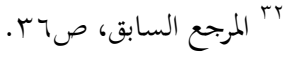




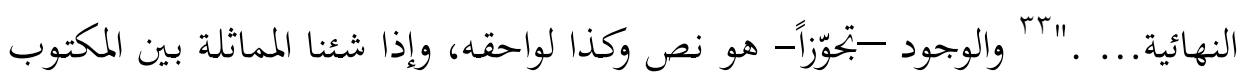

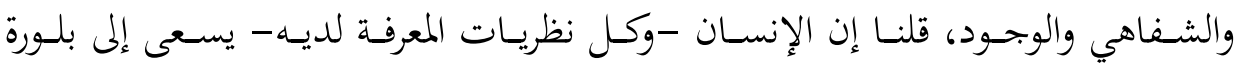
المرجعيات المؤسسة لمعقولية العالم لديه، وإذا قصد إلى فهم ما عند الآخرين فعل الشيء نفسه، فما من مفردة طبيعية أو إنسانية إلا ولها خلفيتها ومرجعيتها.

"وحينما يسلك الإنسان، فإنه لا يسلك بوصفه رد فعل للواقع المادي بشكل مباشر

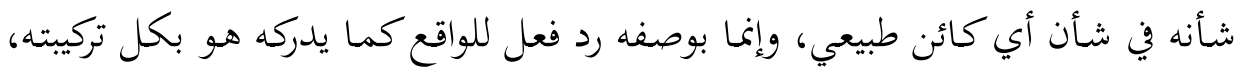
ومن خحلال عقله المبدع الذي يتفاعل ويقيم، ومن خلال ما يسقطه على الواقع من أفراح وأتراح، أو أشواق ومعان، أو رموز وذكريات، ومن خهلال المنظومات الأخلاقية والرمزية

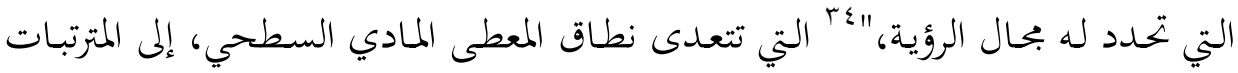

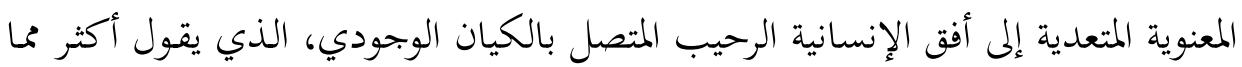

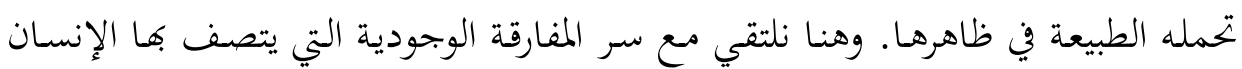

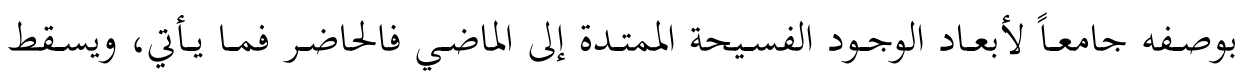
الاعتبارات الملح إليها على إدراكه للأشياء، فيعيها في سياق من المبدئية والمعادية، تشعره

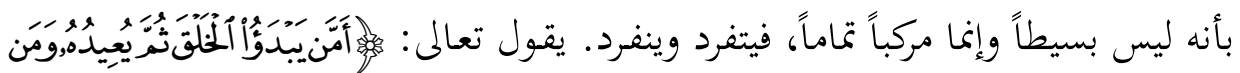

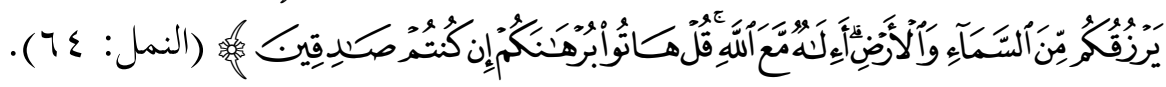

\section{القاعدة الثانية: أصول التكون، ومسبقات التشكل، وسياقاته}

إن إدراك الأمسور في منبتها، والسعي إلى تعرف أصول منشسئها، ومسبقات تكوهـا،

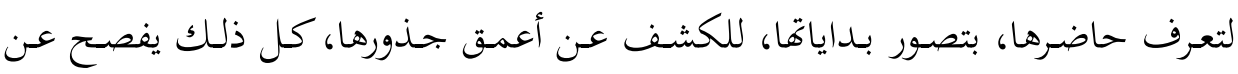
ماهيتها وحقيقتها.

وإذا كانت القاعدة الأولى قد وضعتنا في إطار الفهم العام؛ في بدء الوعي ومنتهاه، فإن الثانية تميل إلى أخذ الوجه الأول من القاعدة السالفة، وتعمل على تركيزه وتطبيقه من فن في

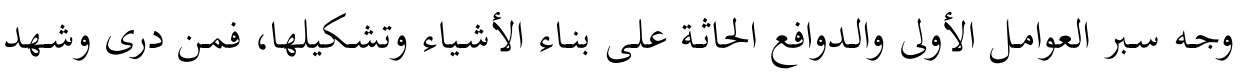


90 المنهج المعري التوحيدي عند عبد الوهاب المسيري: مدخل إلى الإبستمولوجيا التوحيدية الحاج بن أحمنة دواق أسباب الظواهر عرف البواعث التي قامت وراهها، وبالتالي يسهل عليه الإحاطة بالوجه.

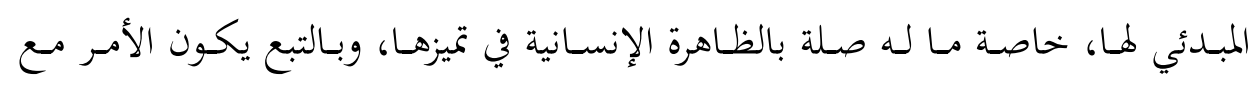
الظواهر الأخرى بوصفها خلاصة العمل البشري ووعيه.

لكن، من اللازم الإلماح إلى تصوير المسيري لحقيقة البشري الإنساني؛ إذ يشير إلى أنه

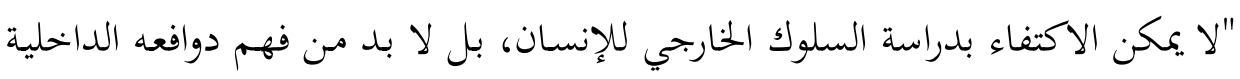

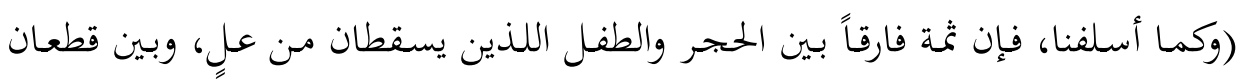

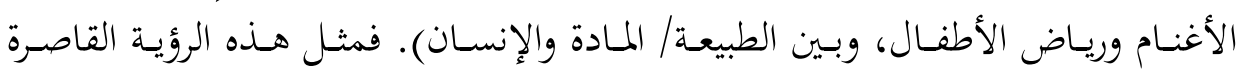

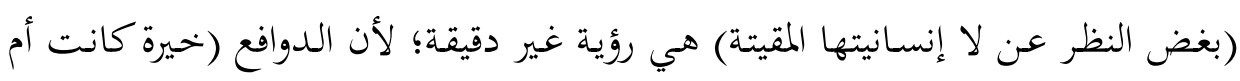

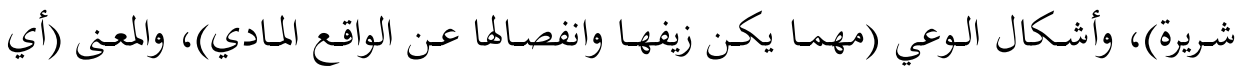
الدلالة الداخلية التي يراها الإنسان فيما يقع له من أحداث وفيما يحيط به من ون ظواهر

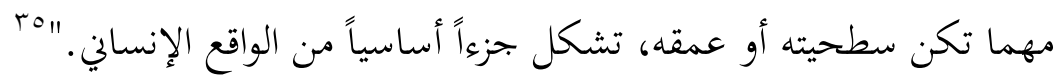

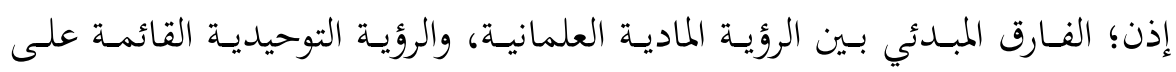
التفسير المفتوح، هو السماح للعناصر الأولى التي كوّنت شخصية الإنسان وبداهته أمـام

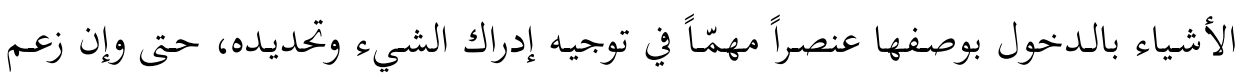

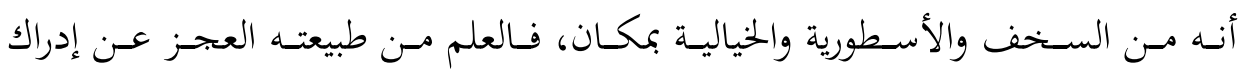
مستويات وجودية تتعدى أسلوبه الإمبريقي المادي، ومن المفترض أن يلتزم إزاءها التواضع

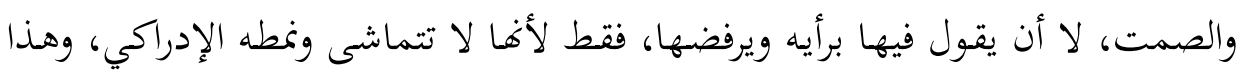

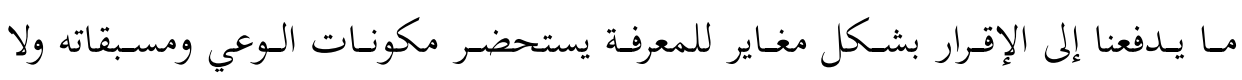

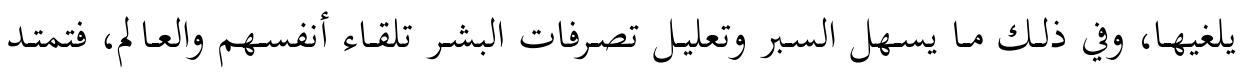
المعقولية وتتشابك اعتباراها حتى إلى العناصر المهمشة والمرفوضة.

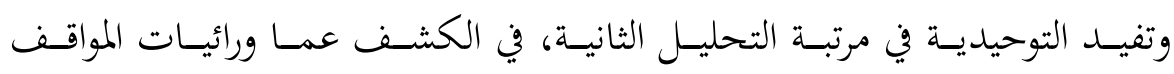
والأحكام والظواهر بتنوعاقا، ويزيد الإثمار معرفيّاً بتناول الوعي البشري بملكاته على فئلى أنه

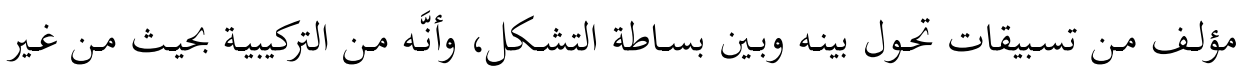


المعقول إسقاط البواعث والأسباب السابقة التي ولدته، ودائماً الظواهر معه، مادية كانت

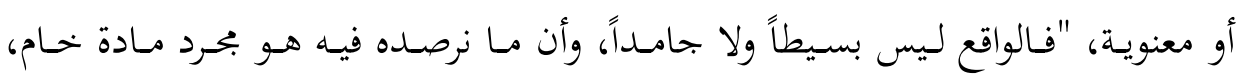

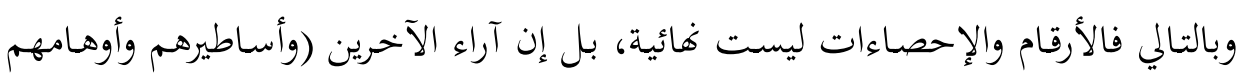

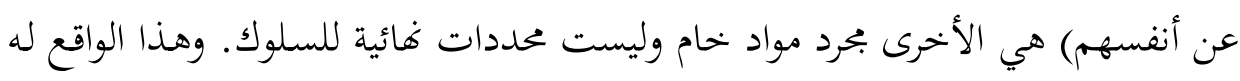

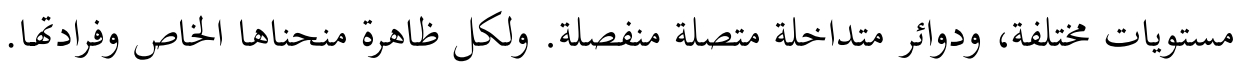
والعلاقة بين العقل والواقع ليست بسيطة ولا آلية. فالفاعل الإنساني لا يستجيب مباشرة للمثير، وإنما يستجيب للمثير كما يتصوره هو نفسه، فالذات بما تحمل من أساطير وهموم

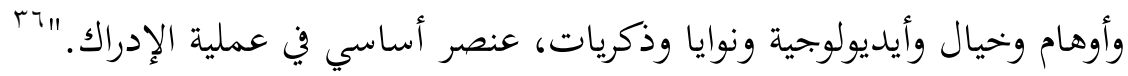
وأود في المستوى الذي بلغناه مـ التحليل، أن أنوه بمسألة غاية في الدقة، وهي أن تمييز المسـيري بـين الظـاهرة الطبيعية والإنسـانية، لا يقود إلى الاعتقـاد بعدم وجـود تشـابه

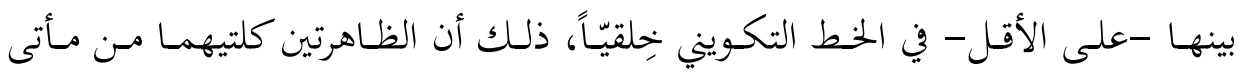
وأفمها إلى مصسير، وتخضـعان لسـنن، وإن تفاوتـت في طبيعتها وفي تحكمها في مفرداتها؛ فالجبرية طبيعيًاً ذات سمات خاصة، وطبائع العمران والاجتماع والنفوس لها سمتها المتميزة. لكن، لكل سـن عمل وتحرك، والفـارق يكمـن في طريقـة التنـاول وأسلوب التعاطي مـع كليهما، إضافة إلى التمايز الجحوهري في خصائصهما. ولا يعتقدن أحسد أن التمييز يقود

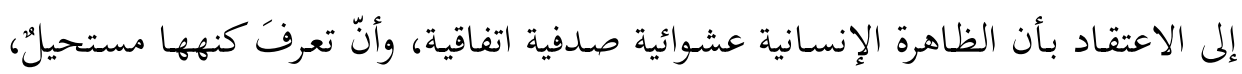

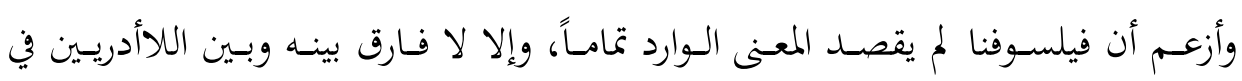

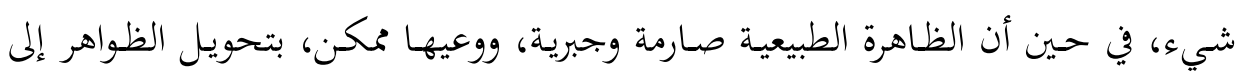

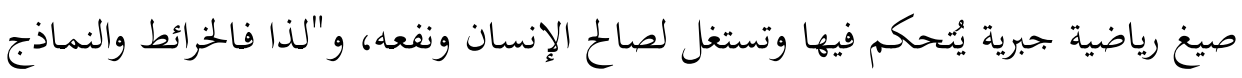

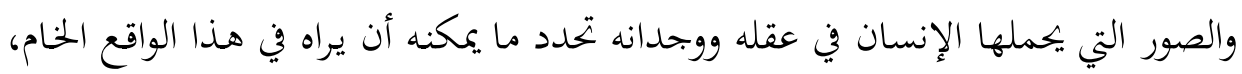
فهي تستبعد وتمشش بعض التفاصيل فلا يراهـا، وتؤكد البعض الآخر بحيث يراهـا هامـة

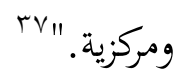

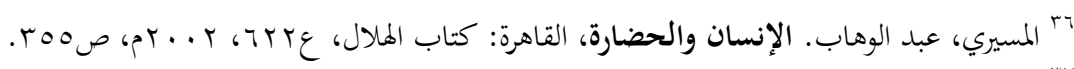
rv المرجع السابق، صبري، المهاب، الإنس 
GV المنهج المعري التوحيدي عند عبد الوهاب المسيري: مدخل إلى الإبستمولوجيا التوحيدية الحاج بن أحمنة دواق

فكل الحضارات -وكثير من البشر فيها- حُبَْلى بالمُسبقات التي شكلت رؤيتها،

وكونت خحارطتها الإدراكية بوحي من العناصر التفكيرية السابقة، التي يستحيل تلافيها في

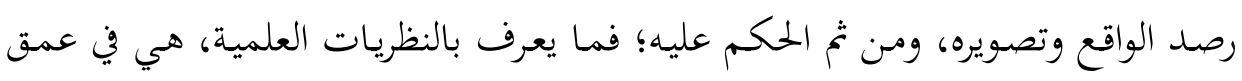
التحليل، وجهات نظر تستجلب معطيات سابقة، فتعمد بوساطتها إلى الإبعاد والتركيز، والإبراز والإخفاء. وحينما تواجهنا ظاهرة غريبة (أو أي ظاهرة)، سنحاول معرفة ظروفها

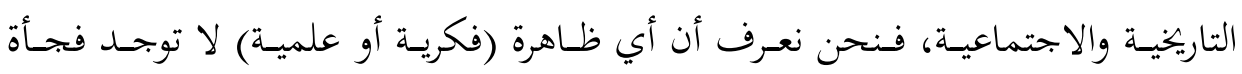

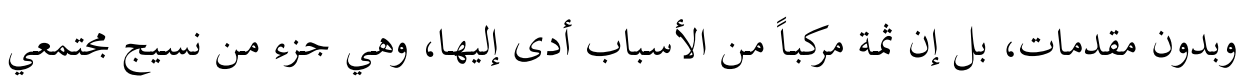

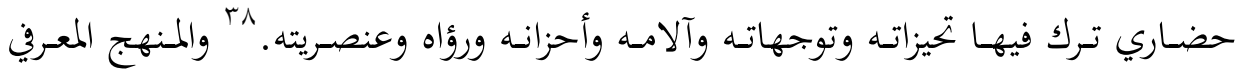
التوحيدي تظهر فاعليته التفسيرية، في كونه يستهـف في القاعدة الثانية، فهم العوامـل

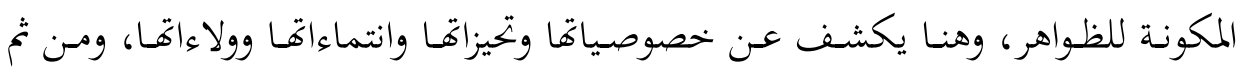
تنتفي مقولة كونيـة المعرفـة وإنسـانيتها الواحـدة والوحيـةة، وهنـا نتـذكر مـا ينعتـه المسـيري بإمبريالية المعرفة، أو اللحظة العلمانية النماذجية الواحدة.

واستنتاجاً "يجب أن نكون مدركين للمنظومة القيمية التي ننطلق منها والفلسفة التي

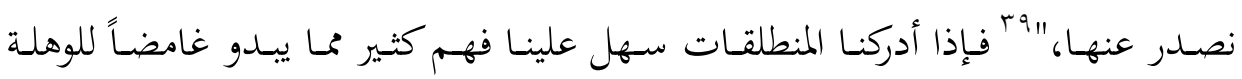
الأولى، وتمكنّا مـن التقويم وفق رؤية خاصة، تملك قوتها بمقدار تناسقها وعدم تناقضها،

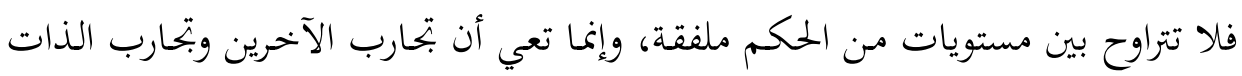

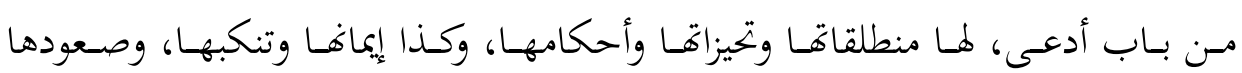

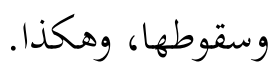

القاعدة الثالثة: الاعتبار بالمآل، والإثمار الأخير، أو الوعي بضريبته وعبئه وهي تتضسمن العمل على تصسور وافتراض هايـة للأشياء كمـا هي، إذا كانست مـن

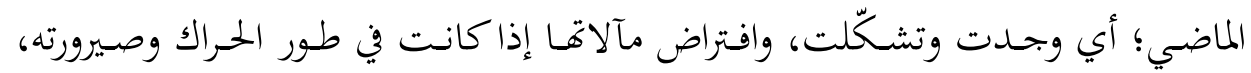

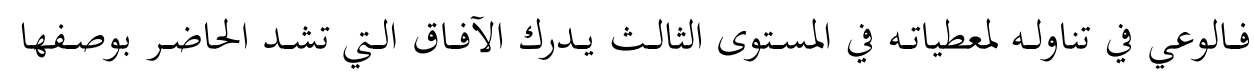

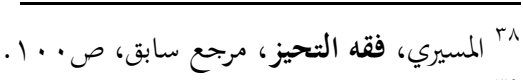

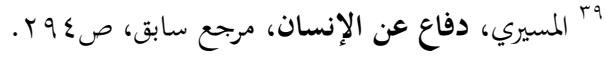


مستقبلاً له، لتعرف محفزات الفكر وغاياته. وهنا من اللازم التمييز في التحليل بين فهاية

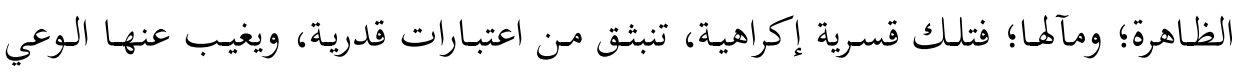
الظاهر. أما هذه فناشئة من اختيار منتبه يعي ما يفهم، ويريد، ويعمل.

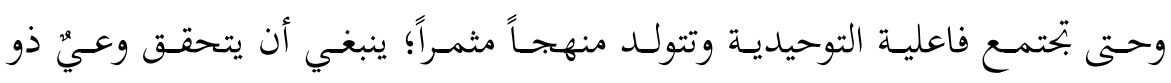

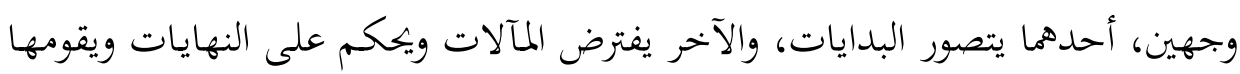
ويناقشها، وبذلك تلتئم أطراف الفهمه، من بدء التصورات ومنبثقها وصولاً إلى معادهـا.

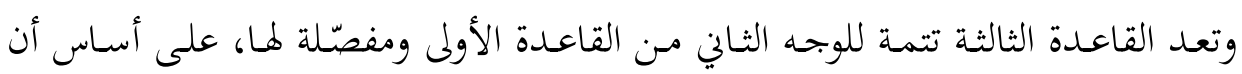

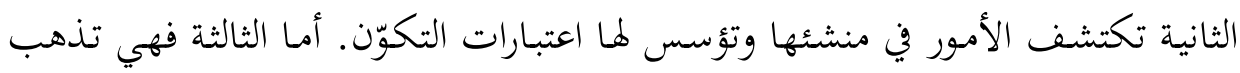

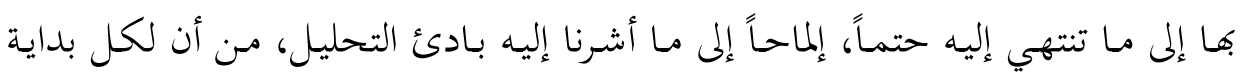

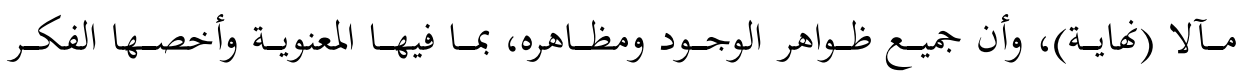

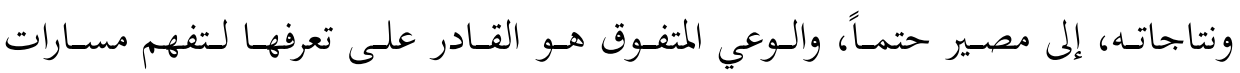

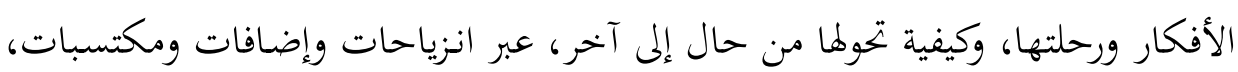
تضيف أو تقلل تبعاً للظروف ورحلئا المحيطة بها.

ولا يغيبن عن خاطرنا تماماً؛ أن التوحيدية كما أفها متفوقة في الكشف والسبر عن مُسبقات الأمور، فهي بالتبع متمكنة من التنبؤ والتوقع لما سيكون، مثلما يفيدها الحال

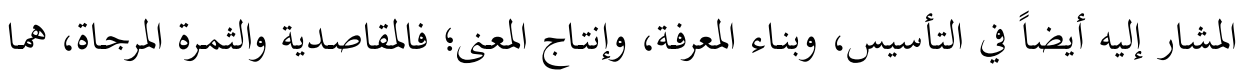

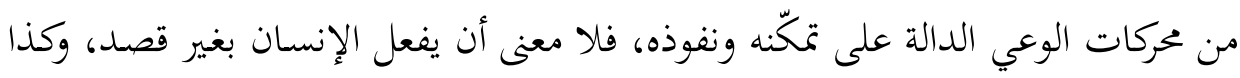

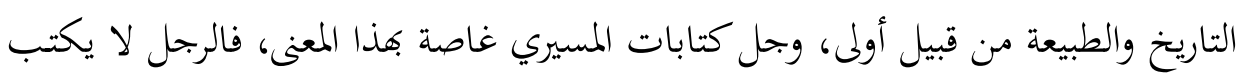

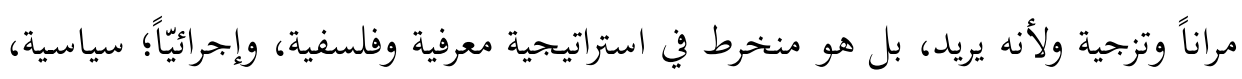

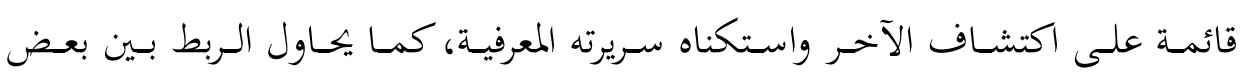

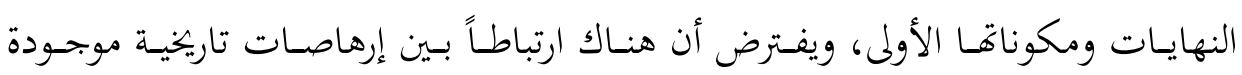
اليوم، ومآلات ستفضي إليها بحربتهم الحضارية، التي ستجر على البشرية كلها سلبيات تركيبتها، وإيجابياتا إن توفرت. 
99 المنهج المعري التوحيدي عند عبد الوهاب المسيري: مدخل إلى الإبستمولوجيا التوحيدية الحاج بن أحمنة دواق

أمـا الغرض مـن وراء العمل العميق الذي قام بـه، فهو فض الارتباط بين المنجزات

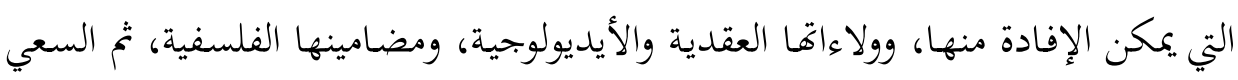

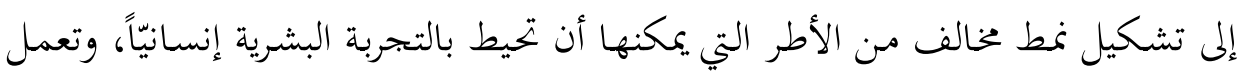

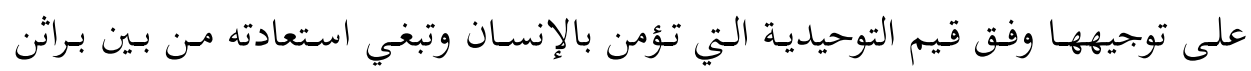

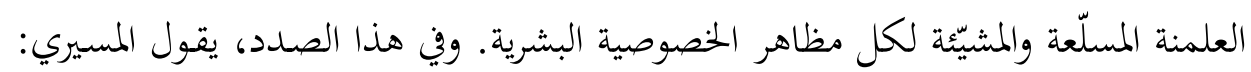

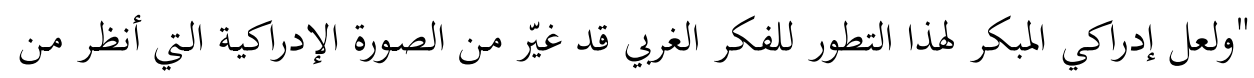

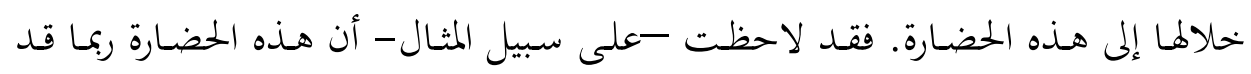

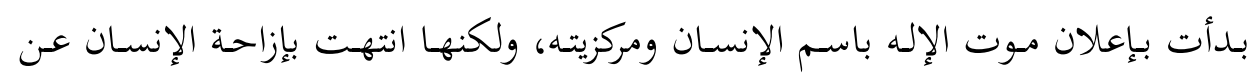

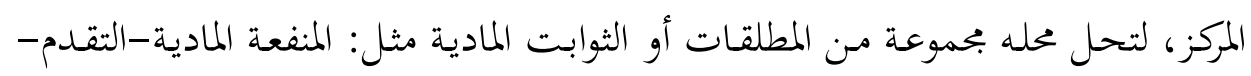

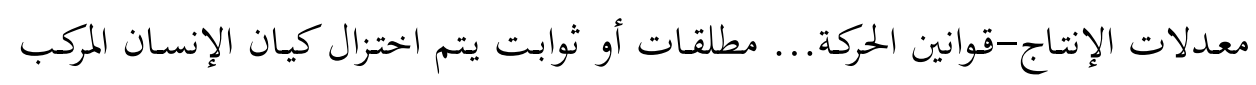

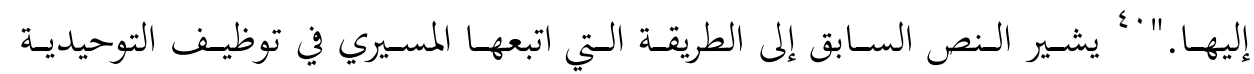

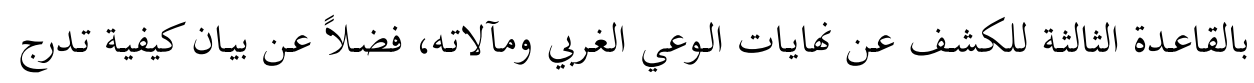

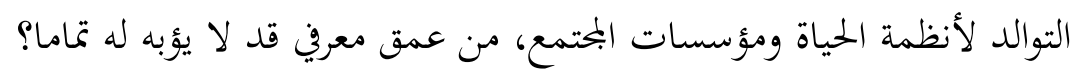
إن تـلازم التوحيدية والتجربـة الإنسانية؛ تأسيساً، وفهماً، وتحليلاً وتفسيراً، وحكماً

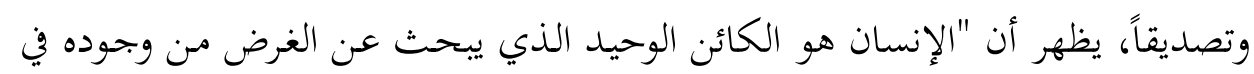

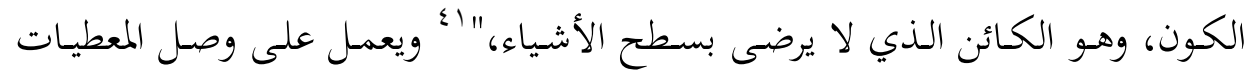

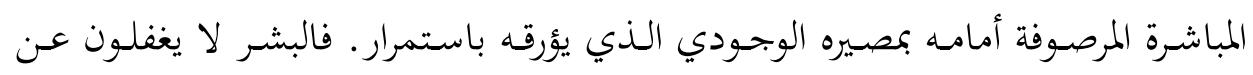

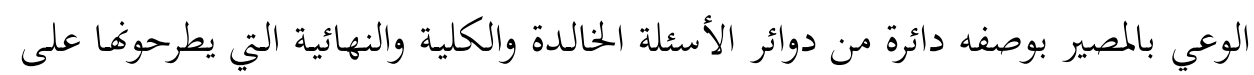

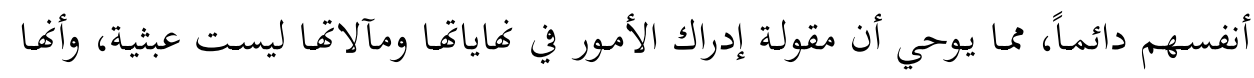

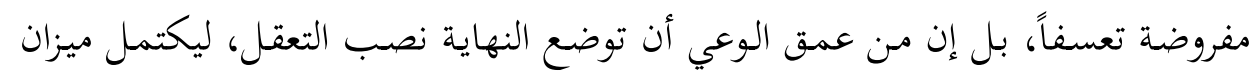

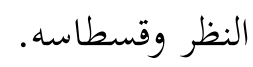

وما يمكننا من طموح القاعدة الثالثة، استصحاب الوارد في التوحيدية نموذجاً، ذلك أن همها أن تقوم "بصياغة نموذج افتراضي يكون بمثابة صورة مصغرة نتصور أهـا تتطابق

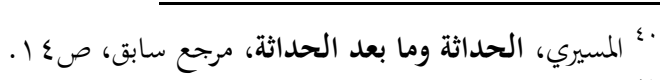

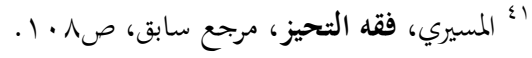


مع العلاقات التي تشكل بنية الظاهرة وتعطيها خصوصيتها، وهذا أمر حتمي لكل من

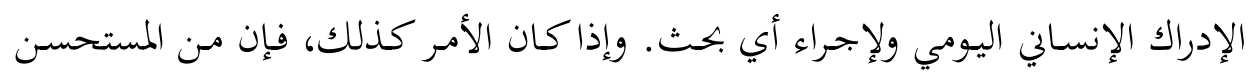

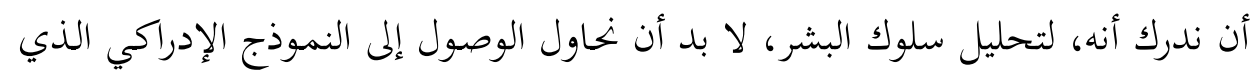

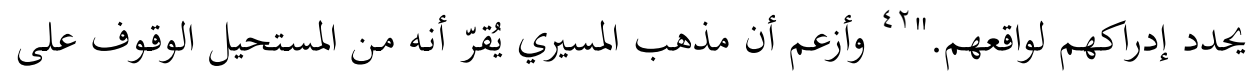

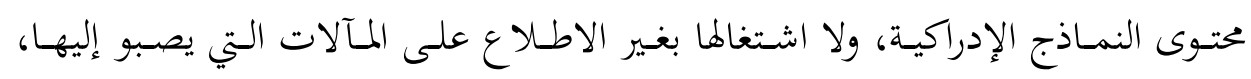

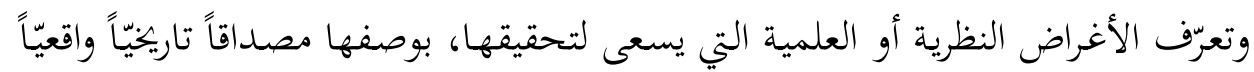

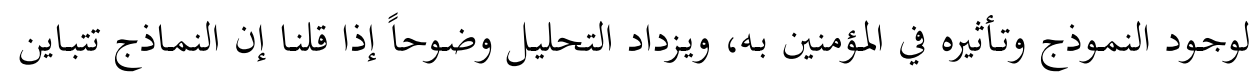
تبعاً لمنطلقاتما والتساوق مع فهاياتما.

يقوم النموذج المعرفي، الذي يمثَّل قاعدة لكل الرؤى البشرية، على ثلاثة تسـاؤلات

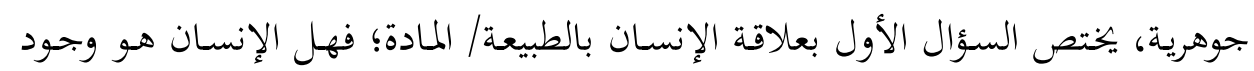

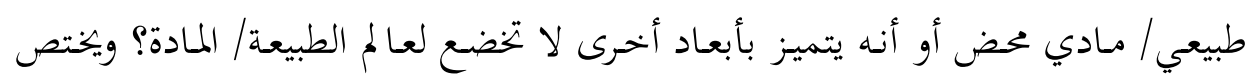

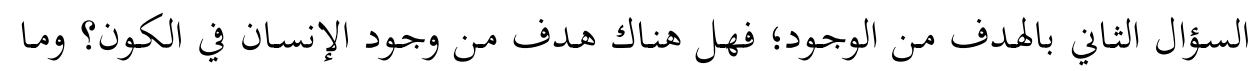

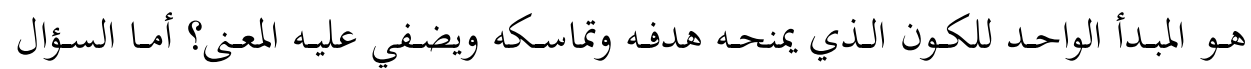

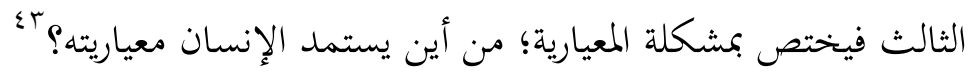

ما يهمني مـ التساؤلات التي ساقها فيلسوفنا، التساؤلان: الثاني والثالث، لكوفما يستبطنان عنصراً ملازماً لوعي الإنسان، مهما تعمقت تبروبته الحضارية أو اتسعت، هو

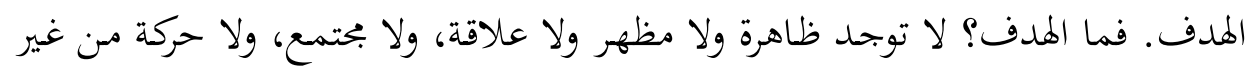

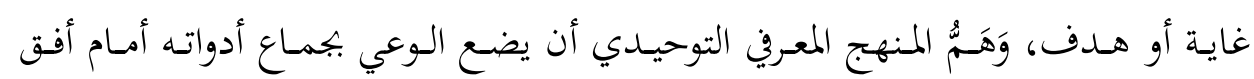

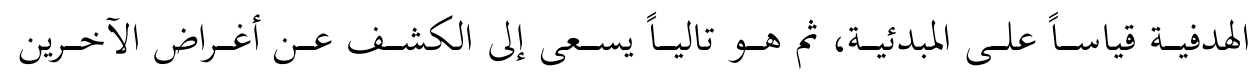

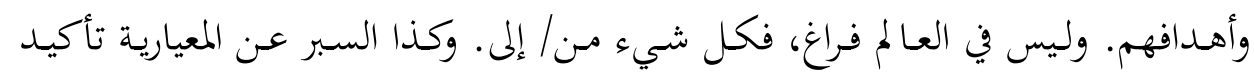

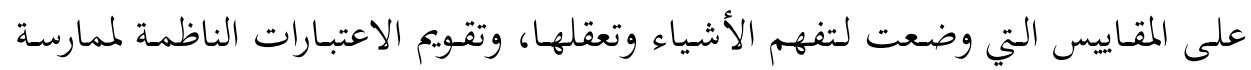
الحياة، بتسديد من الغاية المضمنة في نطاق المبدأ، في حركية وديناميكية فاعلة. "ولتوضيح فكرتنـا، قـد يكـون مـن المفيـد أن نـذكر بحقيقـة بديهيـة، وهي أن كـل الأشياء والظواهر

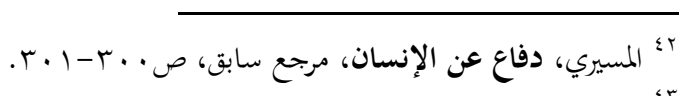

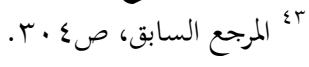


والأفكار المحيطة بنـا، المهـم والتافه، بتسـد نموذجـاً حضـارياً متكاملاً، وتستتند إلى رؤيـة

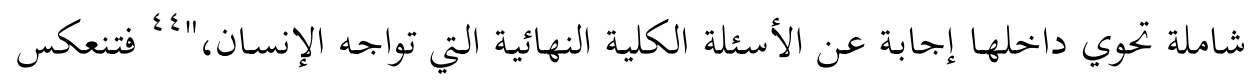

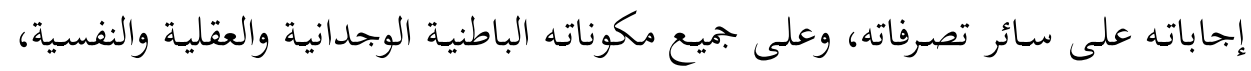

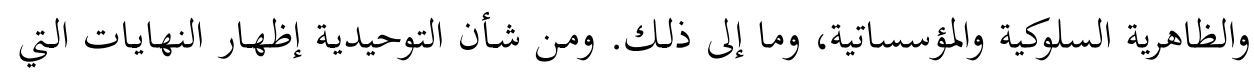

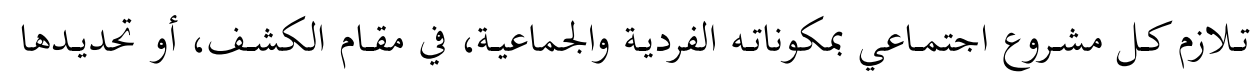
تربويّاً وتعليميّاً وتنظيميّاً في مقام التأسيس.

وتقف التوحيدية بالمعنى السالف ضد الأشكال العدمية في الفهم التي تنكر انشداد الوعي الإنساني إلى أفق الغائية، والعودة بالضمير البشري إلى الدائرة الهدفية من المحفزات

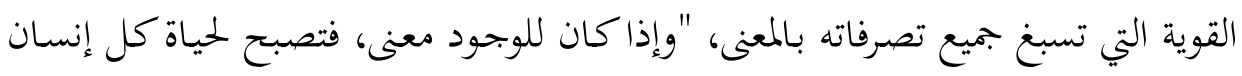

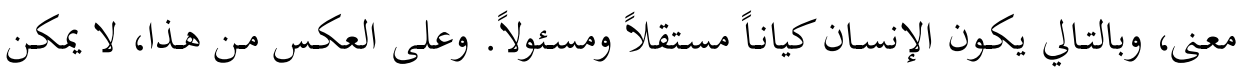

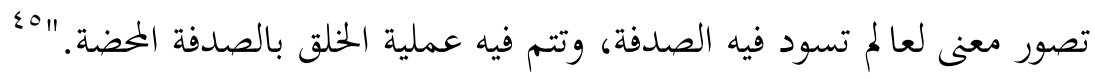

والصـفية لا تنتمي إلى دائرة الأخهاق المباشرة وحسبب، بل هي تأسيساً؛ موقف

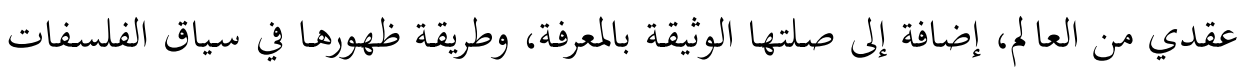

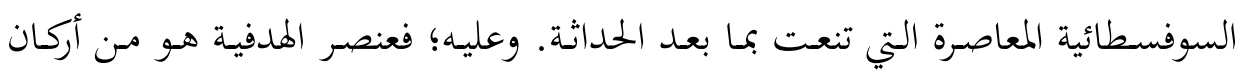

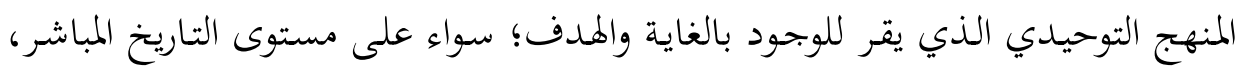
أو الأحداث التي تليه بوصفها نتاجاً له ولمراحل تطوره المتطاولة. وهنا يلتبس معنى الغاية

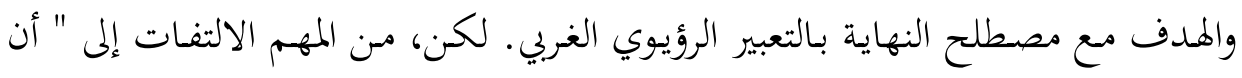

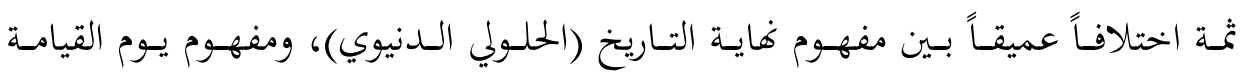

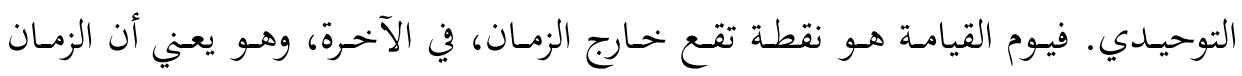

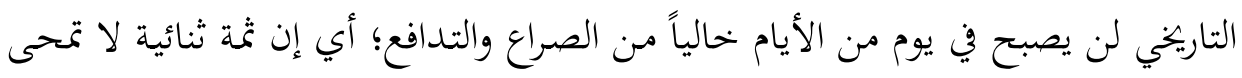

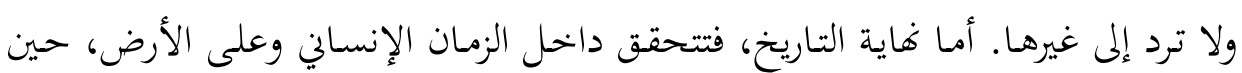

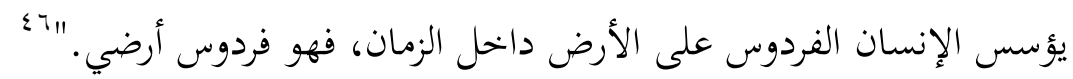

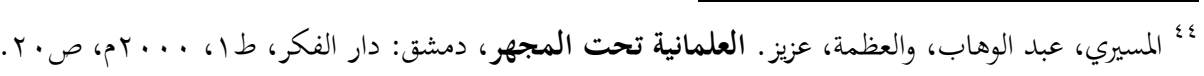

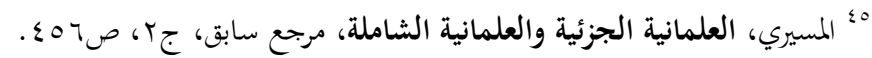

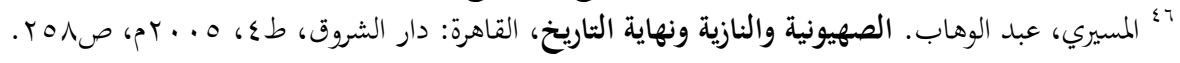


وما يعنينا من المنقول أن المسيري أقر؛ بأنه لا يوجد نسق معرفي أو نموذج حضاري،

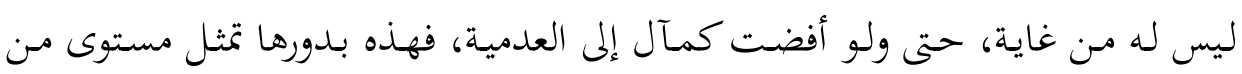
القصد، وإن تلازم مع المباشرة والسطحية والأرضية، غير أنه ليس الوحيد إبستمولوجيّاً،

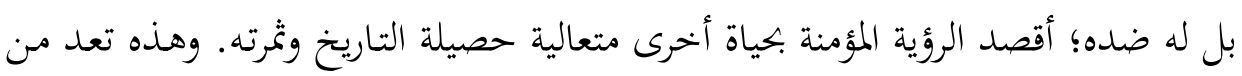
أقوى وأبلغ المحفزات التي تشرط الفعل، وتبعث على الحركة، وتستأمل الأفق باستمرار.

\section{القاعدة الرابعة: الوعي بين الظواهر المتشعبة والإدراك التشابكي}

إن تنـاول كل معطى في سياق شبكة ارتباطات وتواصلات، وبوصفه جزءاً ضمن كل، ينطلق من مبدأ ويؤول إلى معاد، وينعكس عليه مسار المعطيات الأخرى ويتأثر بها، كما ويفعل فيها بدوره، فتحدث جدلية تأثير وتأثر، ضمن دواعي التكون والسير، وكما

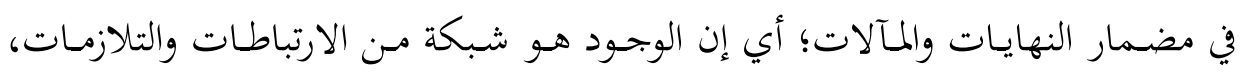

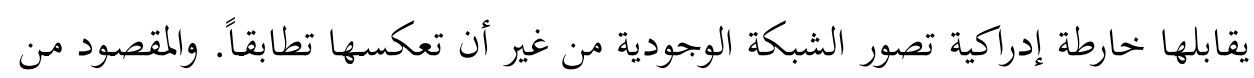
القاعدة الرابعة والأخيرة، هو إبراز أن الظواهر، وإن تتبعنا مسارها مبدئيّاً ومعاديّاً، وتعرفنا

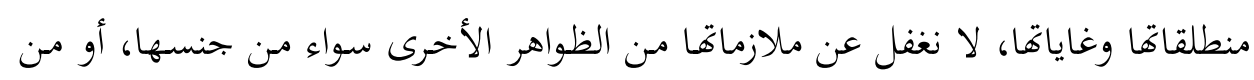
نوع آخر مختلف. فقـد يكون للشيء معنى إذا انفرد واستقل، ويلاصقه آخر على نحو

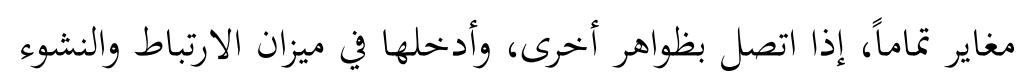

"ومن ثم فإن هذا العلم سيحاول أن يصل إلى خصوصية الظاهرة وتنوعها ومنحاها الخاص وشخصيتها دون أن يهمل عموميتها، كما سيحاول أن يربط الواحد بالآخر دون

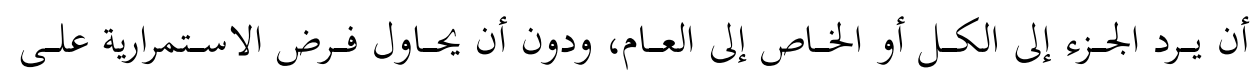

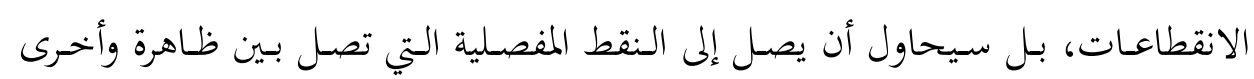

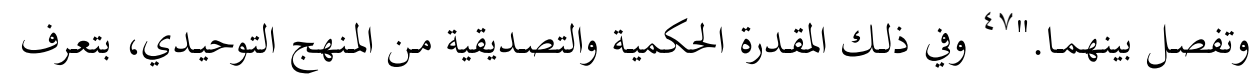

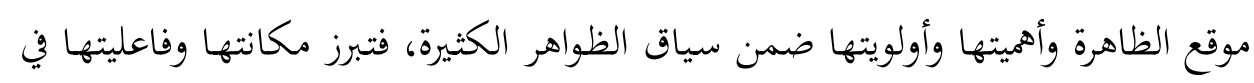
التأثير، حتى تستثمَر أكثر أو تتفادى.

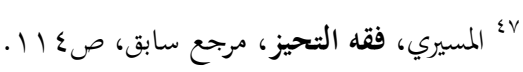


المنهج المعري التوحيدي عند عبد الوهاب المسيري: مدخل إلى الإبستمولوجيا التوحيدية الحاج بن أحمنة دواق ب م. 1.

وفي القاعدة الأخيرة تخنزل جميع القواعد الثلاث السابقة أو تُتَضمن، بوصفها قاعدةً

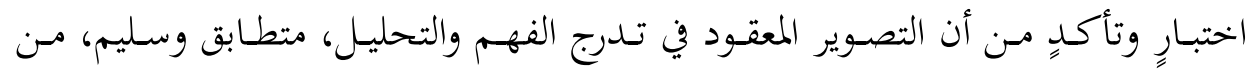

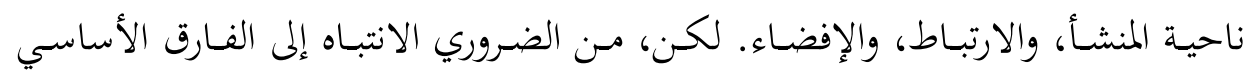

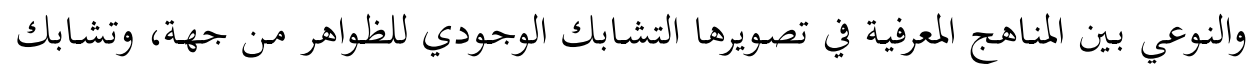

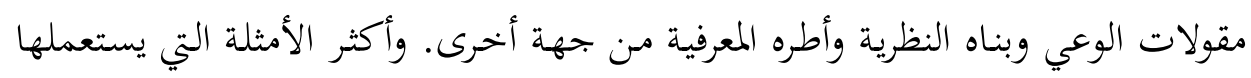

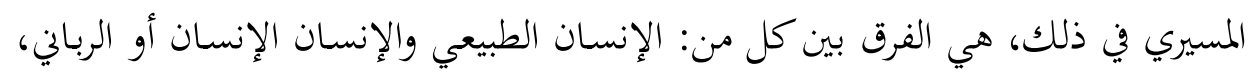

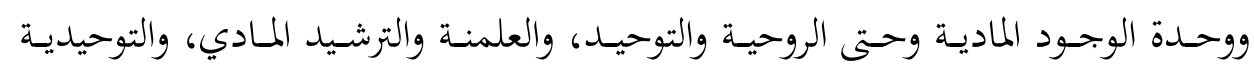

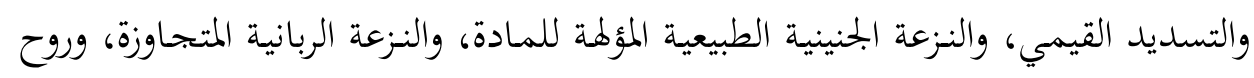
الصراع والسيطرة والإحلال، وروح التكامل والتعاون، والتعاقدية المدنية والتراحية القيمية.

خاتمة:

لو فصَّلْا أكثر في التوحيدية وتطبيقاتا، لما استوعبت بحلدات كثيرة ذلك. ولكن، ما

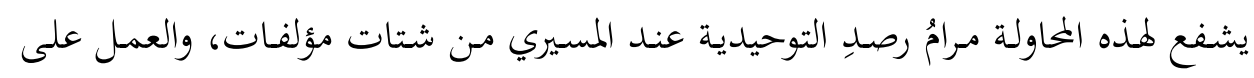
اكتشاف ناظمها النظري الكامن وراء التنوعات والتمثيلات الكثيرة، ويكفينا الإشارة إلى لى

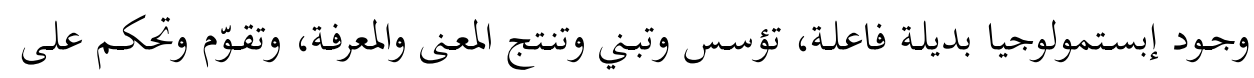

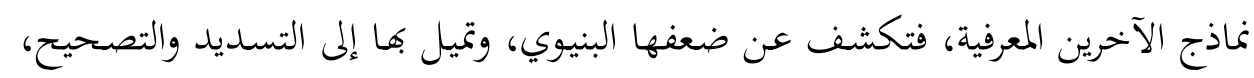

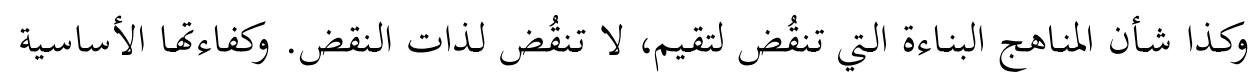
لا تقتصر على قواعدها -على جدواها- وإنما في انغرازهـا في تربة نظرية، تترجم فلسفة

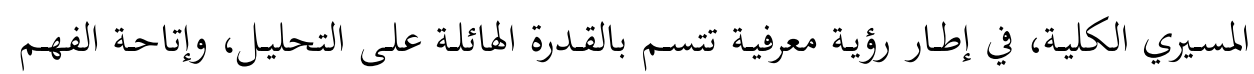

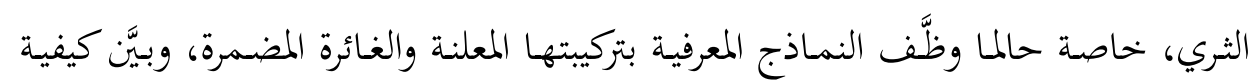
تتبـع تتاليها، في صـورة مركبـة يصعب الإفـلات مـن ضـرورة التماشي معها في تشعباتما المختلفة، وصولا إلى اللحظات المآلات، أو الإفرازات الكثيرة؛ المقصودة وغير المقصودة. وبــلك يكـون المـنهج المعـرفي التوحيــي، متيحـاً للفهـم مـن بلـوغ نوعيـة التحقـق

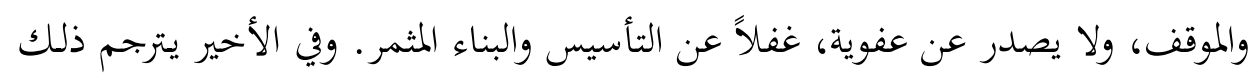


في إطـار مشـروع للحيـاة، مسـتند إلى المعتى المتعـالي المستتعيد للإنسـان الربـاني، والمحتمـع

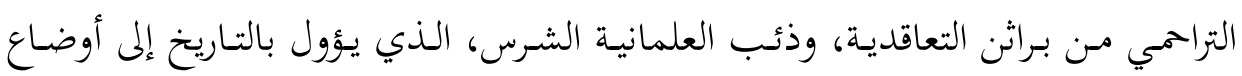
القفص الحديدي؛ أي يفقد كل شيء معناه.

إذن؛ وقوفنا عند ممكن من ممكنات رؤية عبد الوهاب المسيري، في إطار قراءة وتأويل خاص ببعض مضامين مشروعه، لا يغني تماماً، عن ضرورة الانخراط في إطار قراءة نوعية مركبـة تسـتجمع أجـزاء الرؤيـة وعناصـرها، ثم السـبر عـن مسـالك فاعليتها، أو تكوينهـا، وصولاً إلى النموذج المتوازن المثمر، المنعكس على حياة الإنسان من حيث وعن ما هو . 